Portland State University

PDXScholar

$5-19-1971$

\title{
Comparative Study of Lightweight and Normal Weight Concrete in Flexure
}

Mohammad Zareh

Portland State University

Follow this and additional works at: https://pdxscholar.library.pdx.edu/open_access_etds

Part of the Mechanics of Materials Commons, and the Structural Materials Commons Let us know how access to this document benefits you.

\section{Recommended Citation}

Zareh, Mohammad, "Comparative Study of Lightweight and Normal Weight Concrete in Flexure" (1971). Dissertations and Theses. Paper 1483.

https://doi.org/10.15760/etd.1481

This Thesis is brought to you for free and open access. It has been accepted for inclusion in Dissertations and Theses by an authorized administrator of PDXScholar. Please contact us if we can make this document more accessible: pdxscholar@pdx.edu. 
AN ABSTRACT OF THE THESIS OF MOHAMNAD ZAREH for the Master of Science In Applied Science presented May 19, 1971.

Title: Comparative Study of Lightweight and Normal Weight Concrete in Flexure.

APPROVED BY NEMBERS OF THE THESIS COMMTTTEE

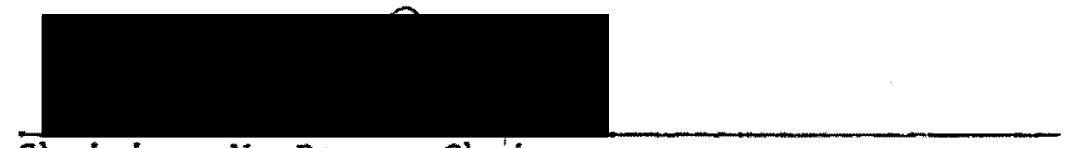

Shriniwas N. Pagay, Chairinan

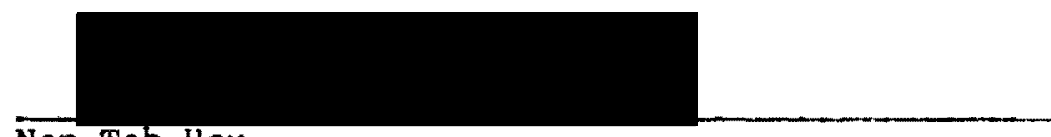

Nan-Teh Hsu

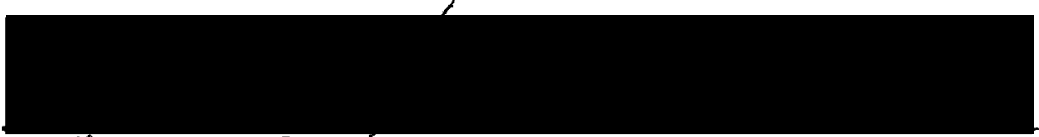

Hacïk Erzurumlu

This investigation represents a comparative study of the

flexural behavior of lightweight and normal weight concrete. Both

theoretical and experimental moment-curvature characteristics of

the tested specimens were used to study the flexural behavior.

A generalized computer program to determine the moment-curvature relationships of a singly reinforced rectangular concrete beam was developed.

For this 1 imited study it was observed that lightweight concrete beams when compared to normal concrete beams achleve comparable moment capacity (about $92 \%$ of normal weight concrete) but exhibit higher deflectlons (about $40 \%$ more than normal weight concrete): 
COMPARATIVE STUDY OF LIGHTNEIGH'T AND NORMAL WEIGHT CONCRETE IN FLEXURS

$$
\text { by }
$$

MOHAMMAD ZAREH

\footnotetext{
A thesis submitted in partial fulfillment of the requirements for the degree of

\section{MASTER OF SCIENCE \\ in \\ APPLIED SCIENCE}

Portland State University

1971 
TO THE OFFICE OF GRADUATE STUDIES :

The members of the committee approve the thes is of Mohammad Zareh presenter May 19,1971.

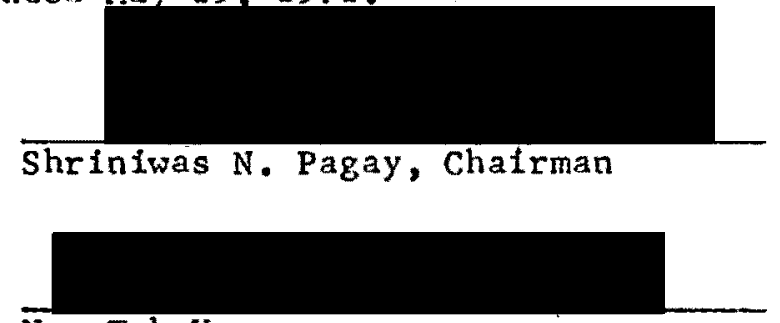

Nan-Teh Hsu

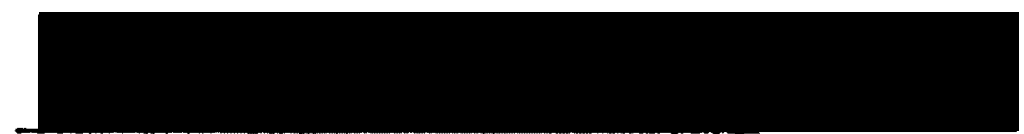

Hacik Erzurumilu

APPROVED :

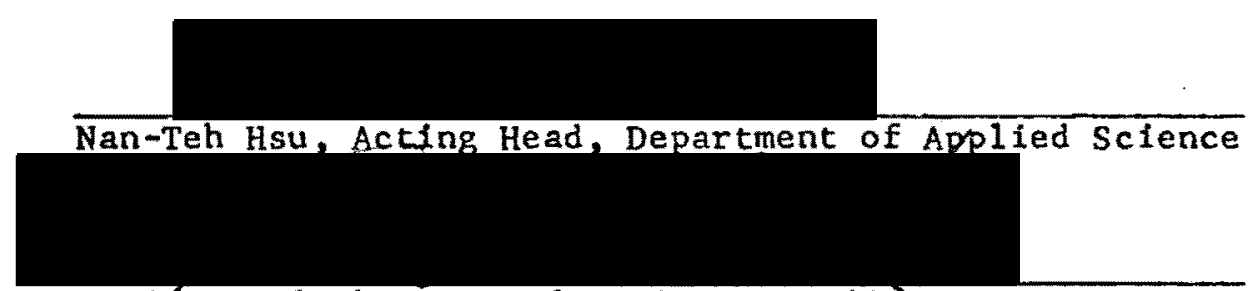

David T. Clark, Dean of Graduate Studies- 
DEDICATED

TO

PARVIN, HABIB, BARBARA, FRUZ, AND ROYA 


\section{ACKNOWLEDGMENTS}

The author wishes to express his sincere appreclation to the members of his thesis committee for their helpful suggestions. Particular thanks are extended to the author's thesis adviser Dr. S. N. Pagay who gave willingly of his time and ability through helpful supervision.

The author is grateful to the following companies for donating materlals: Empire Lite-Rock Inc., Oregon Portland Cement Company, and Mercer Steel Company.

Thanks are due to Mr. George Laszlo of Empire Prestress for providing literature on properties of lightweight aggregates, and to Mr. J. L. Bargar, director of North Pacific Dlvision Material Laboratory Corp of Engineers, for allowing the use of their testing machine.

Deepest gratitude goes to the author's wife, Barbara, whose patience, encouragement and typing assistance were so indispensable during this important period. 
TABLE OF CONTENTS

PAGE

ACKNOWLEDGMENTS . . . . . . . . . . . . . .

LIST OF TABLES. . . . . . . . . . . . . . .

vil

LIST OF FIGURES ......................

viil

CHAPTER

I INTRODUCTION .................

1.1 Scope of Work. ..............

1.2 Brief Description of Tests .........

1.3 Notations. . . . . . . . . .

II A GENERAL REVIEN OF LIGHTWEIGHT CONCRETE . . .

2.1 General. . . . . . . . . . . .

2.2 Historical Background. . . . . . . .

2.3 Lightwe1ght Aggregates ..........

2.4 Different Processes. . . . . . . . .

Rotary Kiln Process............

Sintering Process. . . . . . . . . .

Machine Process...............

2.5 Physical Properties of Lightweight Concrete.

Compressive Strength . . . . . . . .

Unit Wefght. . . . . . . . . . . . .

Modulus of Elasticity. . . . . . . .

Creep. . . . . . . . . . . . . .

Shear......................

Durability ..................

Bond .....................

Fire Endurance . . . . . . . . . . .

Sumnary. . . . . . . . . . . . . . 
III THEORETTCAL MOMENT CURVATURE RELATIONSHIP . .

3.1 Stress-Strain Relationship. . . . . .

3.2 Moment Curvature Relationship.......

3.3 Development of the Theoretical Moment Curvature Relationship. . . . . . .

3.4 Computer Analysis of Monent Curvature . .

IV MATERIALS, INSTRUMENTATION AND TEST PROCEDURE -

4.1 Reinforcing steel ............

4.2 Concrete Materials............

4.3 Forms ................

4.4 Casting and curing............ 26

4.5 Specimen Dimensions ............... 26

4.6 Testing Equipment and Instrumentation... 26

4.7 Test Procedure. . . . . . . . . . 28

v ANALYS IS OF TEST DATA AND CONCLUSION. . . . . 30

5.1 Curvature ............ 30

5.2 Moment. . . . . . . . . . 31

5.3 Failure Characteristics ........ 32

5.4 Test Analysis................ 32

5.5 Conclustons ................. 34

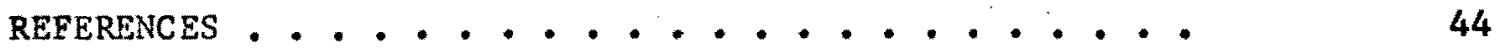

APPENDIX . . . . . . . . . . . . . . . . . 46 


\section{LIST OF TABLES}

TABLE

PAGE

I Mix Design For Lightweight Concrete Test Beams. - .

II Mix Design For Normal Weight Concrete Test Beams. . 


\section{LIST OF FIGURES}

FIGURE

PAGE

1. Spectruin of Lightweight Concretes .......

2. Hognestad Stress-Strain Curve For Concrete in

Flexure ..................

3. Desayi and Krishnan Stress-Strain Curve For

Concrete in Flexure .............

4. Curvature and Moment. . . . . ......

5. Typical Moment-Curvature Curve. . . . . .

6. Finite Element Approximation. ........

7. SOLVE - Logic Diagram to Calculate Tension and Compression Forces. . . . . . . . . .

8. SOLVE - Logic Diagram to Calculate Moment ..

9. SUBROUTINE TC - Logic Diagram to Calculate

Tension Force and Curvature ...........

10. SUBROUTINE STRS1 - Logic Diagram to Calculate

Compression Force Using Desayi and Krishnan

stress-strain Equation. . . . . . . . .

11. SUBROUTINE STRS2 - Logic Diagram to Calculate

Compression Force Using Hognestad Stress-Strain Equation. . . . . . . . . . . . . .

12. Test Specimen Details ...........

13. Typica1 Loading For Test Specimens. ...... 
14. Typical Test set up ............. .

15. Typical Test Beam Roller Supports . . . . .

16. Calculation of Experimental Curvature.....

17. Typical Loading, Shear, and Moment Diagrams .

18. Specimen R-1 and L-1 After Test was Completed *

19. Specimen $\mathrm{R}-2$ and $\mathrm{L}-2$ After Test was Completed.

20. Moment-Curvature Curves For Specimen R-1. . .

21. Moment-Curvature Curves For specimen L-1. . .

22. Experimental Moment-Curvature For Specimens

$\mathrm{R}-1$ and $\mathrm{L}-1$. . . . . . . . . . .

23. Theoretical Moment-Curvature For Specimens

$\mathrm{R}-1$ and $\mathrm{L}-1$...............

24. Moment-Curvature Curve For Specimen R-2 ....

25. Moment-Curvature Curve For Specimen L-2 . . .

26. Experimental Moment-Curvature Curves For

Specimens $\mathrm{R}-2$ and $\mathrm{L}-2$............

27. Theoretical Moment-Curvature Curves For Specimens

R-2 and $\mathrm{L}-2$................ 


\section{CHAPTER I}

\section{INTRODUCTION}

\section{1 scope of Work}

The purpose of this investigation was to study the flexural behavior of lightweight concrete in comparison with normal weight concrete. Both theoretical and experimental moment-curvature relationships were used as a basis for this study.

To develop the monent-curvature $(M-\phi)$ curve a stress-gtrain relationship was required. Several of these relationships $(1,2)^{*}$ were studied and finally the equation proposed by Desayl and Krishnan $(3,4)$ was chosen. The theoretical M- $\varnothing$ curves were developed using an electronic digital computer.

In order to appreclate the advantages and disadvantages of lightweight concrete a knowledge of its physical characteristics would be desirable. Hence, chapter II is devoted to a general review of important properties of lightweight concrete.

\subsection{Brief Description of Tests}

Four concrete beams were tested, two using lightweight aggregate (expanded shale) and the other two using normal weight aggregate (grave1). In all the specimens natural sand was used

\footnotetext{
* Numbers in parenthesis refer to the references at the end of this thesis.
} 
as the fine aggregate.

Two different percentages of high strength reinforcing steel (ASTM A615) were used; test beams $R-1$ and $L-1$ with 0.33 square inch of steel and $\mathrm{R}-2$ and $\mathrm{L}-2$ with 0.22 square inch. Details of the test procedure are given in sec. 4.7 .

\subsection{Notations}

The following notations are used throughout this thesis. The symbols are defined below and where they appear first in the text.

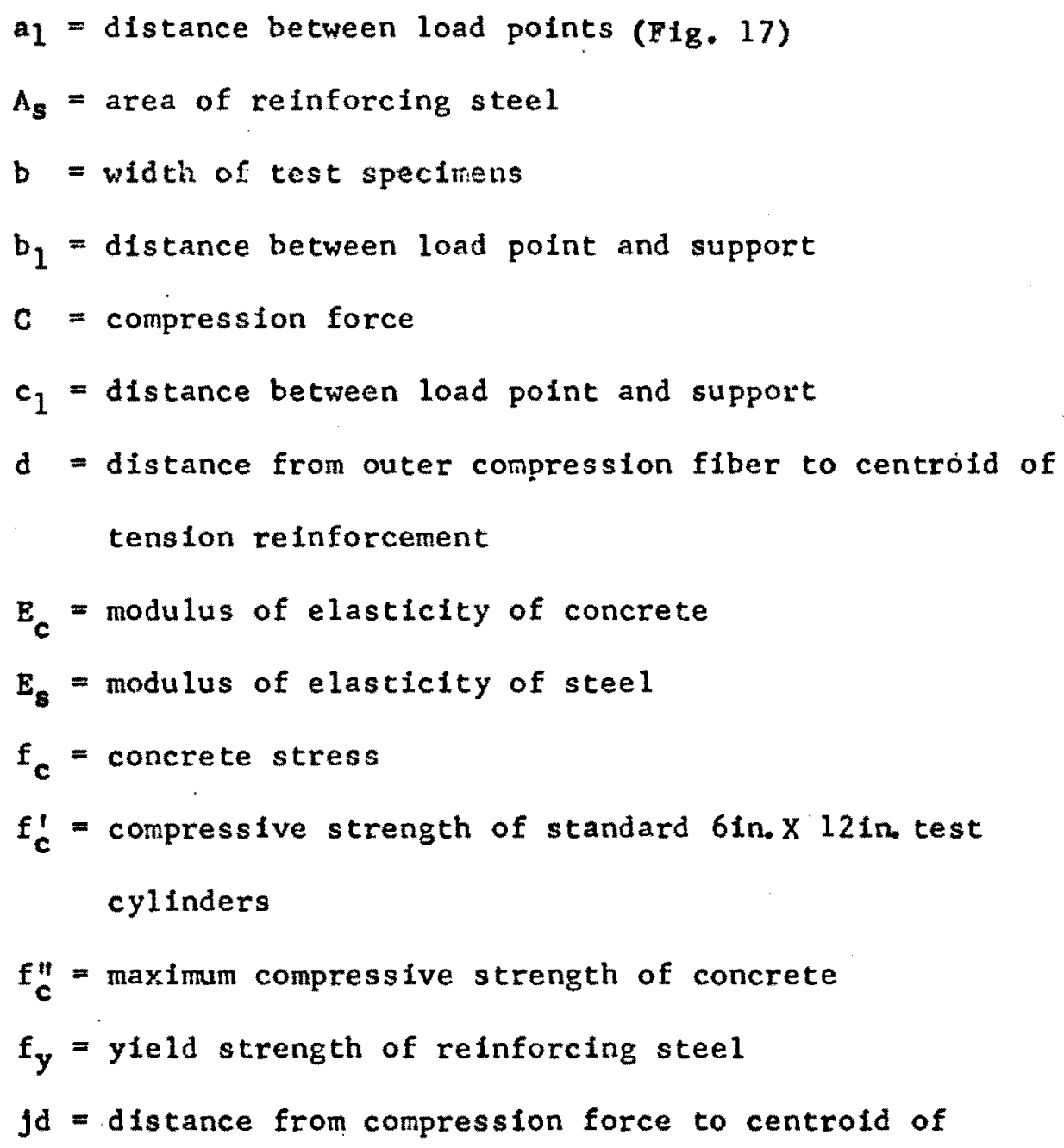




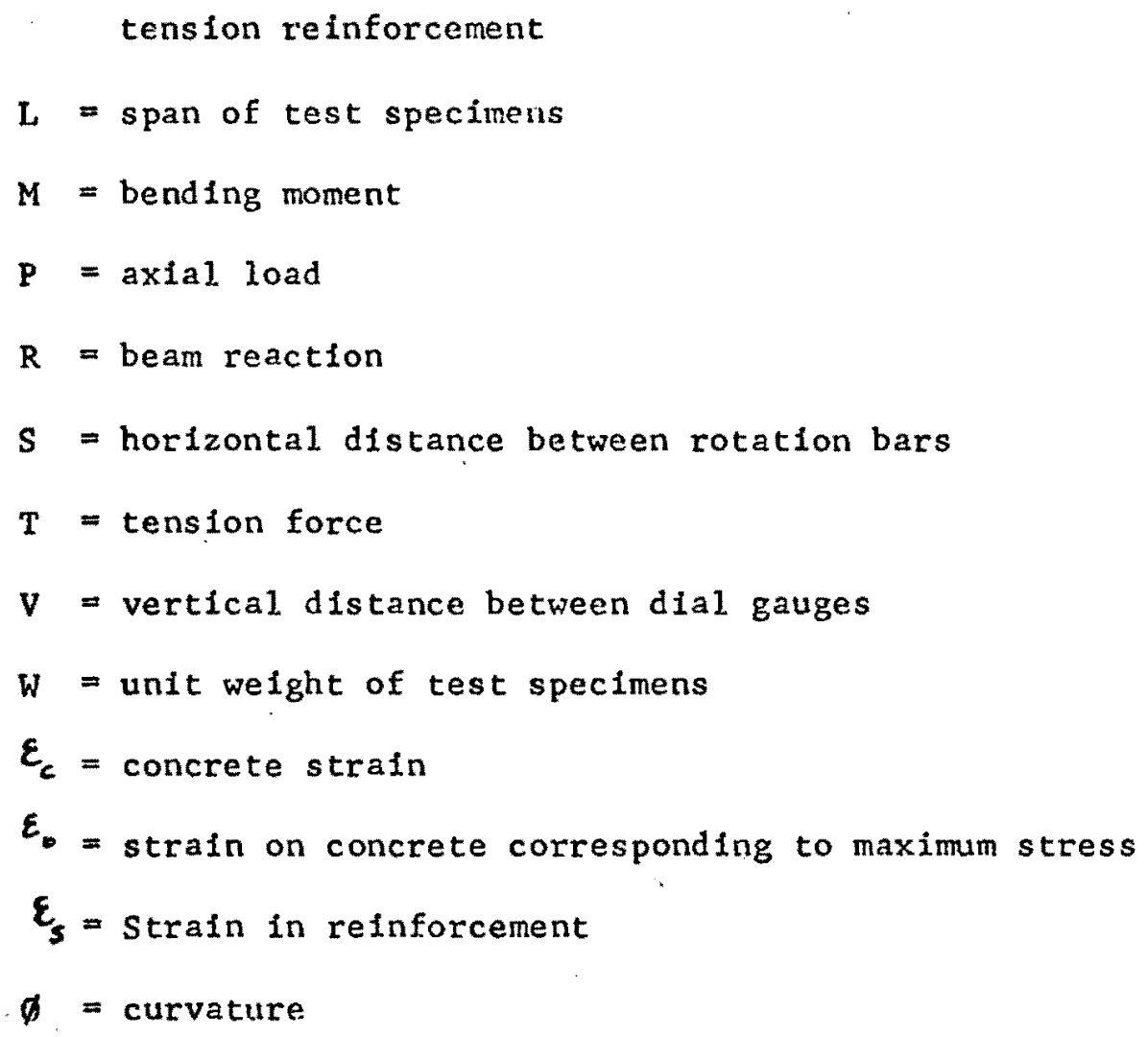




\section{CHAPTER II}

\section{A GENERAL REVIEN OF LIGHTWEIGHT CONCRETE}

\subsection{Genera1}

Freedom of architectural design, together with high compressive strength of concrete, have greatly attributed to its role as one of the major building materials in the world. Structural concrete can be divided in two categories: lightweight and normal weight. Basically, lightwelght structural concrete is still concrete; a cement and water paste is the binder. Expanded clay, slate, shale, or slag is used as the aggregate instead of gravel. As the name implies lightweight concrete has a lower unit weight, about $2 / 3$ of that of normal weight concrete. This reduction in weight when considered in design of buildings could allow the reduction in sizes of some structural members thereby providing more usable space. This would result in a more suitable and economical structure. Unfortunately the reduced unit weight of lightweight concrete is accompanied by its higher cost and some different structural properties compared to that of normal weight concrete. Thus, in deciding between 1 ightwelght and normal welght concrete, careful consideration should be given to their price and their physica1 characteristics. 
2.2 Historical Background

The modern lightweight aggregate industry (5) was first started in 1917, when Stephen J. Hayde developed a process for heat expansion of shales and clays into lightweight aggregates. These aggregates were used to make concrete of substantial strength and low weight. At about the same time F. J. Straub discovered the use of bituminous coal cinders as an aggregate for manufacture of concrete masonary units.

One of the earliest uses of lightweight concrete (6) was in production of a few ships during World War 1 , and in a more than one hundred ships and barges during World War II.

After World War II, extensive studies of lightweight aggregates were conducted by the Housing and Home Finance Agency (7), the National Bureau of Standards, and the U. S. Bureau of Reclamation. These studies led to substantial use of lightweight concrete in building frames, bridge decks, and precast products.

From $1950^{\prime}$ s to present, many multistory structures have been designed utilizing the advantages of reduced dead weight of lightweight concrete.

\subsection{Lightweight Aggregates}

There are many types of lightweight aggregates available, but not all are structurally suitable. Low density concretes are mainly used for insulation purposes. They have a low unit weight (around 50 pef) and low compressive strength (ranging from 100 to 1000 psi). Fig. 1 shows a spectrum $(6,8)$ of lightweight concretes. 

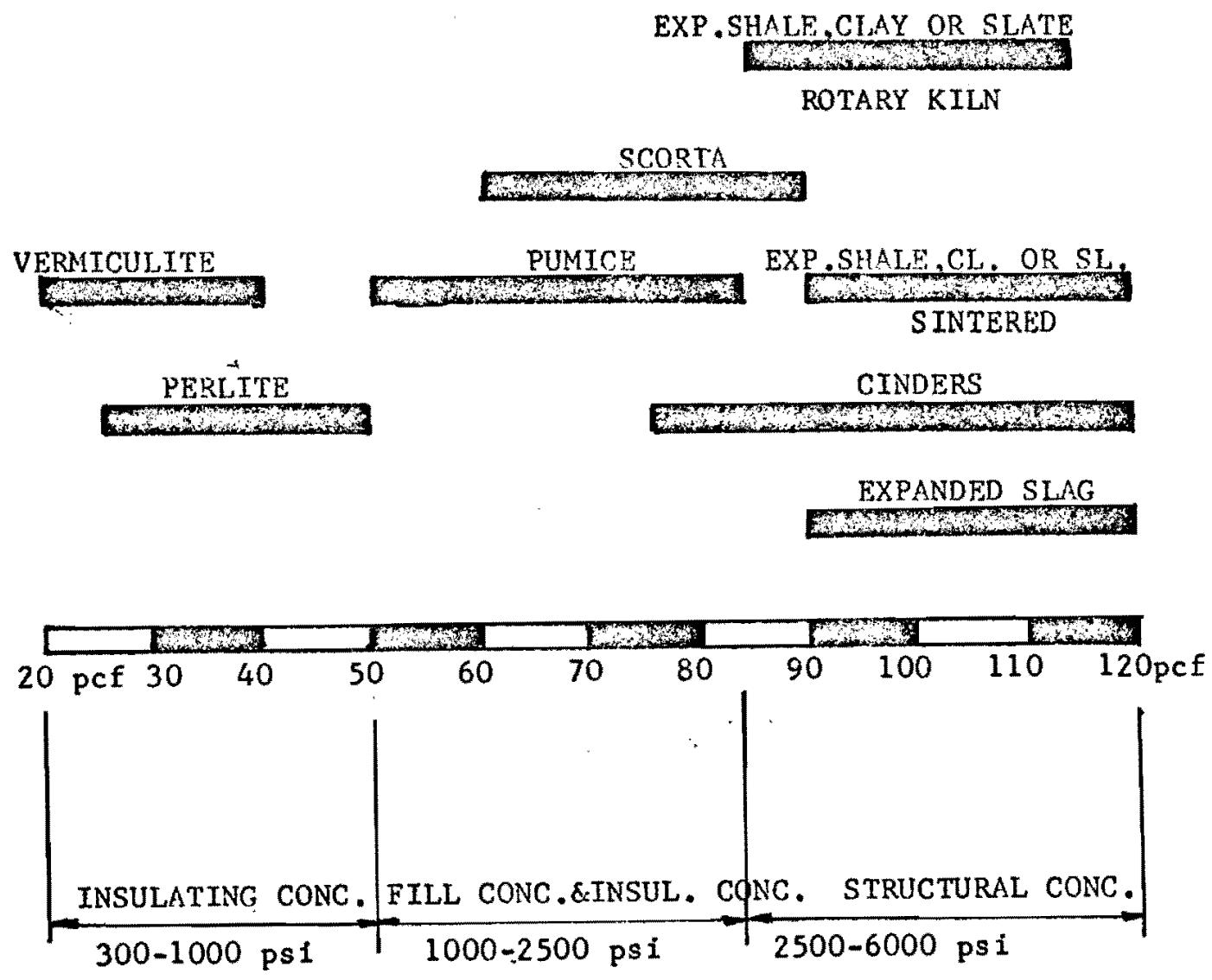

Fig. 1. Spectrum of lightweight concretes.

Structural lightwelght concrete as defined by the American Concrete Institute (6) shall have a 28 -day compressive strength in excess of 2500 psi and a 28-day unit weight not exceeding 115 pcf. Raw materials used in commercial production of structural lightweight aggregates are generally (a) suitable natural deposits of shales, clays, or slates; (b) by-products of other industries, such as iron blast furnace slags or fly ash.

There are several different methods (6) of producing structural lightweight aggregates, e.g., rotary kiln process, sintering process, and machine process. 


\subsection{Different Processes}

\section{Rotary Kiln Process}

This process is used mainly with expanded shales and clays which exhibit a bloating characteristic. The raw material is introduced in a rotary kiln and is heated to a temperature varying from $1600^{\circ} \mathrm{F}$ to $2100^{\circ} \mathrm{F}$, depending on the raw material. The aggregate is heated to a point of becoming soft and pliable, but not to a point of complete melting.

The raw material is changed into a product with an internal cellular structure. This cellular structure when cooled becomes a vitreous hard material.

\section{Sintering Process}

The raw materials used in sintering process contain some burning fuel. They either contain carbonaceous matter or are mixed with finely ground coal or coke. The material is introduced in special burners where gases are formed causing the expansion of the material and thereby creating its cellular structure.

Machine Process

The slag is melted at temperatures in excess of $2200^{\circ} \mathrm{F}$ and is rapidly agitated in a machine while adding a controlled amount of water. Then the slag is cooled and crushed. The cellular structure is created by entrapment of the evolved gases. 


\subsection{Physical Properties of Lightweight Concrete}

Compressive Strength

Compressive $(6,9)$ strength comparable to that of normal weight concrete is obtained by the use of lightweight concrete. High compressive strengths of up to 7000 psi are used in the production of structural precast members. However, general1y more sacks of cement per cublc yard of concrete are required when manufacturing lightweight concrete instead of normal welght concrete.

\section{Unit Weight}

The unit weight $(6,9)$ of lightweight concrete is significantly lower than that of normal weight concrete, due to the cellular structure of the aggregate. The unit weight of lightweight concrete, depending on the type of fine and coarse aggregate used, varles from 90 to 120 pcf. The unit weight is also greatly affected by graduation and partide shape. Higher strength lightweight concrete has a somewhat higher unit weight since more sacks of cement per cubic yard of concrete are used.

\section{Modulus of Elasticity}

Static modulus (10) of elasticity is taken as the slope of the secant to the stress-strain curve. Over the years several expressions for modulus of elasticity of concrete have been developed. One that has appeared frequently in codes is $1000 f_{c}^{\prime}$. This formula and others, are reasonably accurate for concretes of usual strength made of normal welght aggregates. 
However, the increased use of lightweight aggregates and also higher strength concretes created the need for a more accurate expression.

Adrian Pauw (11) analyzed a large number of test data for concrete of different densities and arrived at the following empirical equation.

$$
E_{c}=33 W^{1.5} \sqrt{f_{c}^{\prime}}
$$

Where $E_{c}=$ elastic modulus, psi

$W=$ unit weight, pcf

$f_{c}^{\prime}=$ concrete compressive strength, psi

The above formula gives the values of modulus of elasticity for both lightweight and normal weight concrete and is adopted by the current American Concrete Institute Code. For this study Pauw's empirical formula was used to determine the theoretical modulus of elasticity of the tested spectinens

\section{Creep}

Creep is the dimens lonal change or increase in strain of concrete due to a sustained load. There have been numerous research programs involved in determining the creep properties of lightweight concrete.

Creep strain of lightweight concrete (6) varies from about equal to double that of normal welght concrete. Tests have shown that the use of higher strength concrete, steam curing, or the use of sand to replace lightweight fines 
reduces this variation.

Shear

Lightweight concrete $(12,13)$ in relation to normal weight exhibits lower tensile strength, especially when subjected to alr drying. Because shear capacity of structural members is directly related to the diagonal tension resistance of the concrete, i.e., its tensile strength, a lower shear strength is attributed to lightweight concrete.

Durability

In addition to laboratory tests, the use of lightweight concrete $(6,10)$ in bridge decks has shown that lightweight concrete has an equal or better resistance against freezing and thawing compared to that of normal welght concrete.

Bond

In comparative tests of lightweight and normal weight concretes there appears to be slightly $(6,10)$ lower pull-out capacity for lightweight concrete. However, the difference is small enough so that the American Concrete Institute Code allows the same capabllities for both concretes.

\section{Fire Endurance}

Due to its lower $(6,10)$ thermal conductivity, lightweight concrete is more fire resistant than normal weight concrete. 
Summary

Modulus of elasticity of lightweight concrete is about

$1 / 2$ to $3 / 4$ th that of normal weight concrete.

Creep and shrinkage vary from about equal to double that

of normal weight concrete.

Lightweight concrete when air dried shows less diagonal

tension resistance.

Lightweight concrete is a better insulator and has more

fire resistance. 
THEORETICAL MOMENT CURVATURE RELATIONSHIP

\subsection{Stress-Strain Relationships}

To deternine the theoretical moment-curvature curve a stress-strain relationship is required. However, due to nonlinear stresstrain characteristics of concrete, many empirical formulas $(1,2)$ have been proposed.

In 1951 Hognestad (14) proposed a stress-strain relationship for concrete in flexure. Hognestad's proposed curve, which has been widely accepted, is shown in Fig. 2 .

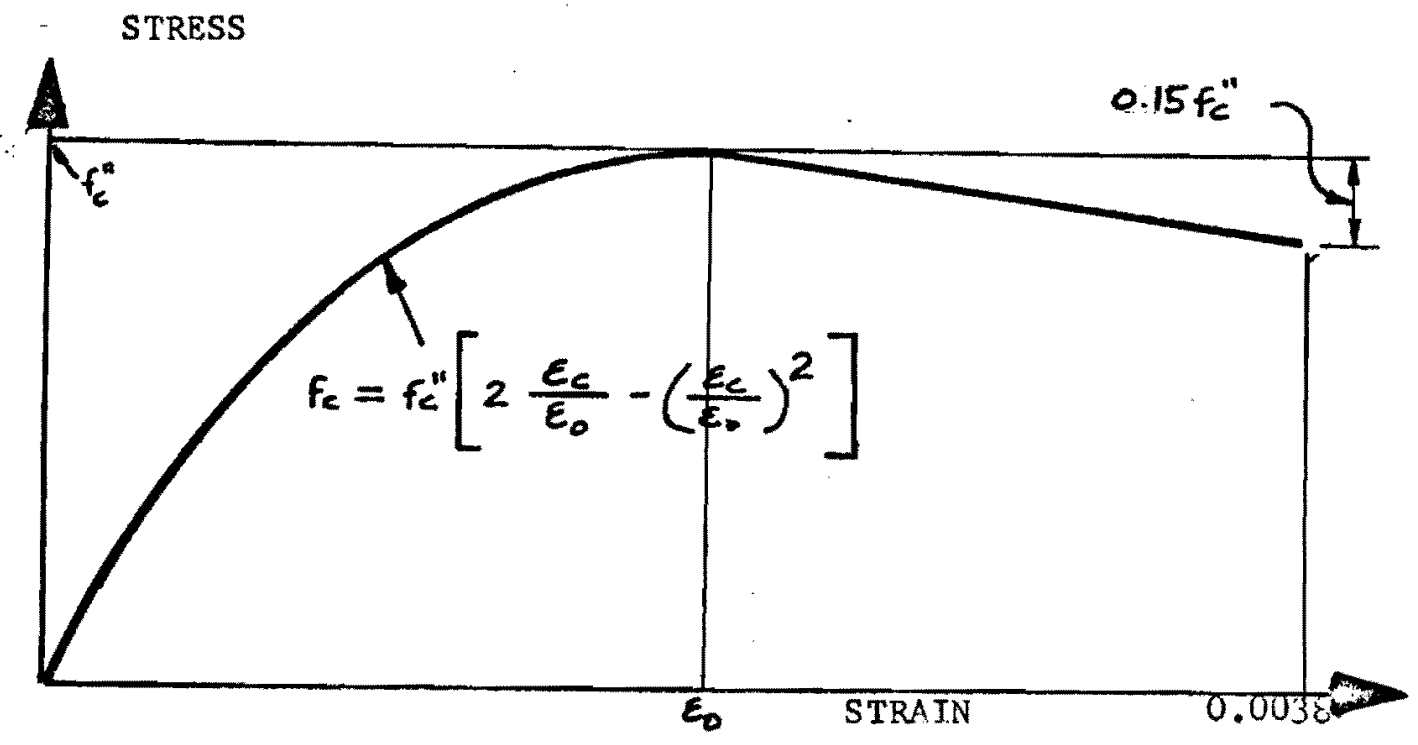

Fig. 2. Hognestad stress-strain curve for concrete in flexure. 
The ascending portion of the curve is represented by the formula:

$$
f c=f_{c}^{\prime \prime}\left[\frac{2 \varepsilon_{c}}{\varepsilon_{0}}-\left(\frac{\varepsilon_{e}}{\varepsilon_{0}}\right)^{2}\right]
$$

Where $\varepsilon_{0}=2 \mathrm{f}_{\mathrm{c}}^{\prime \prime} / \mathrm{E}_{\mathrm{c}}$

$$
f_{c}^{\prime \prime}=0.85 f_{c}^{\prime}
$$

The descending portion of the curve is defined by a straight line which starts at the maximum stress value and falls to a value of $0.85 f^{\prime \prime}$ at a strain of 0.0038 . This is the ultimate strain where concrete is assumed to fail.

Desayi and Krishnan (3), in 1964, proposed a new simplified equation. This equation represents both the ascending and the descending part of the stress-strain curve. Desayl and Krishnan's proposed stress-strain relationship is shown in Fig. 3 .

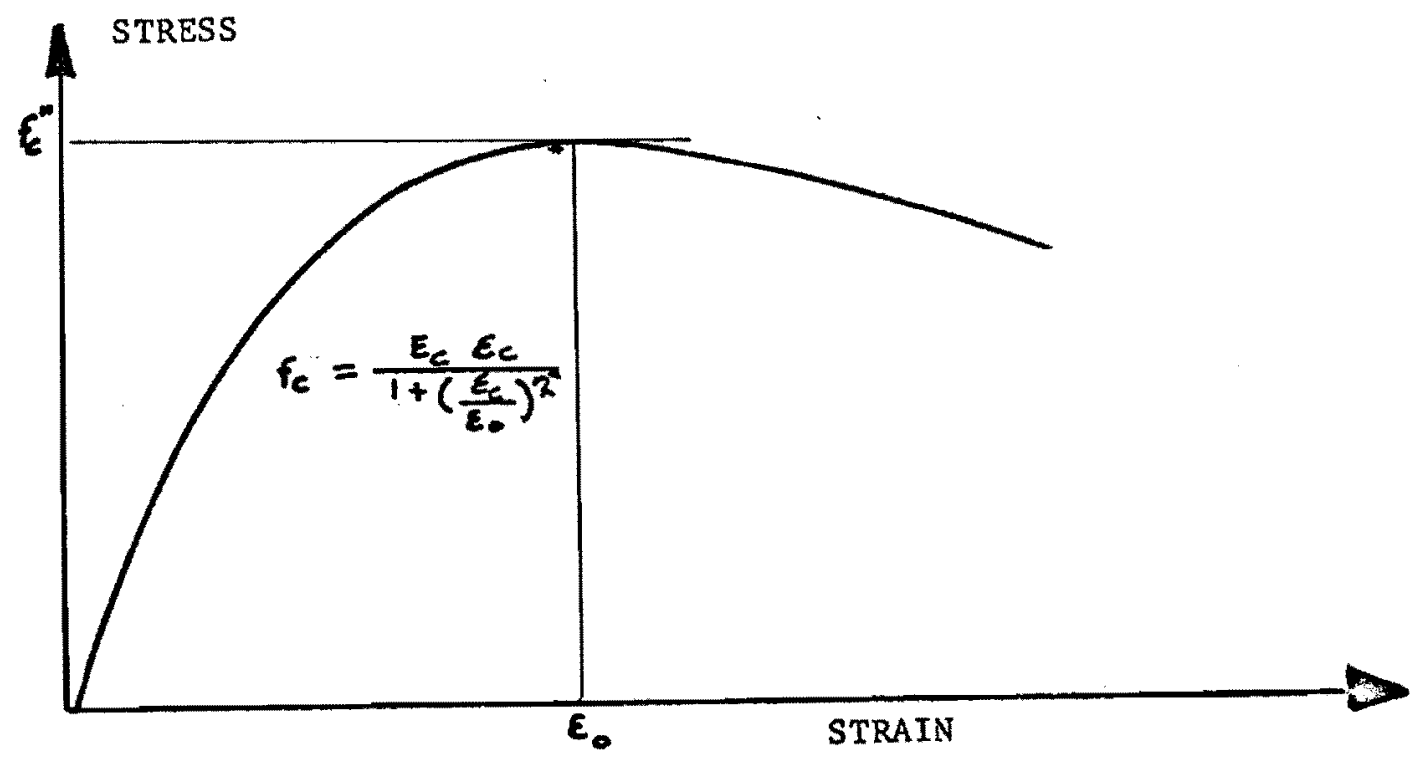

Fig. 3. Desayi and Krishnan stress-strain curve for concrete in flexure. 
Where $\varepsilon_{0}=2 \mathrm{f}_{c}^{\prime \prime} / \mathrm{E}_{\mathrm{c}}$

$$
\mathrm{f}_{\mathrm{C}}^{\prime \prime}=0.85 \mathrm{f}_{\mathrm{c}}^{\prime}
$$

Due to their simplicity and their use by other researchers, the stress-strain equations proposed by Hognestad and the one by Desayi and Krishnan were first chosen for this study. Both of these equations were used in a computer program and the resultIng moment-curvature curves were plotted. The ascending portion of the curves using Desayi and Krishnan's equation was remarkably close to that of Hognestad's.

Since Desayi and Krishnan's equation represents both the ascending and the descending part in a single expression it was subsequently used as the basis for comparison in the analysis of test results.

\subsection{Moment Curvature Relationship}

The relationship between bending moment and the resulting deformation of flexural nembers is characterized by their moment-curvature curves.

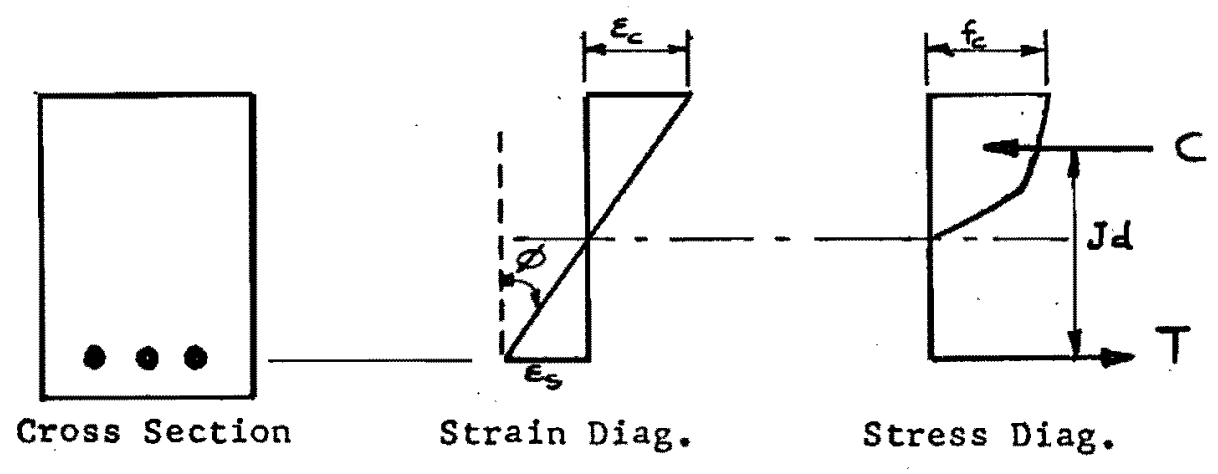

Fig. 4. Curvature and moment 
As is shown in Fig. 4 angle measured by the concrete and steel strains represents the curvature of a specimen.

Moment is taken as the product of compression or tension force ( $C$ or $T$ ) times the moment arm designated as jd. Fig. 5 shows a typical moment-curvature curve.

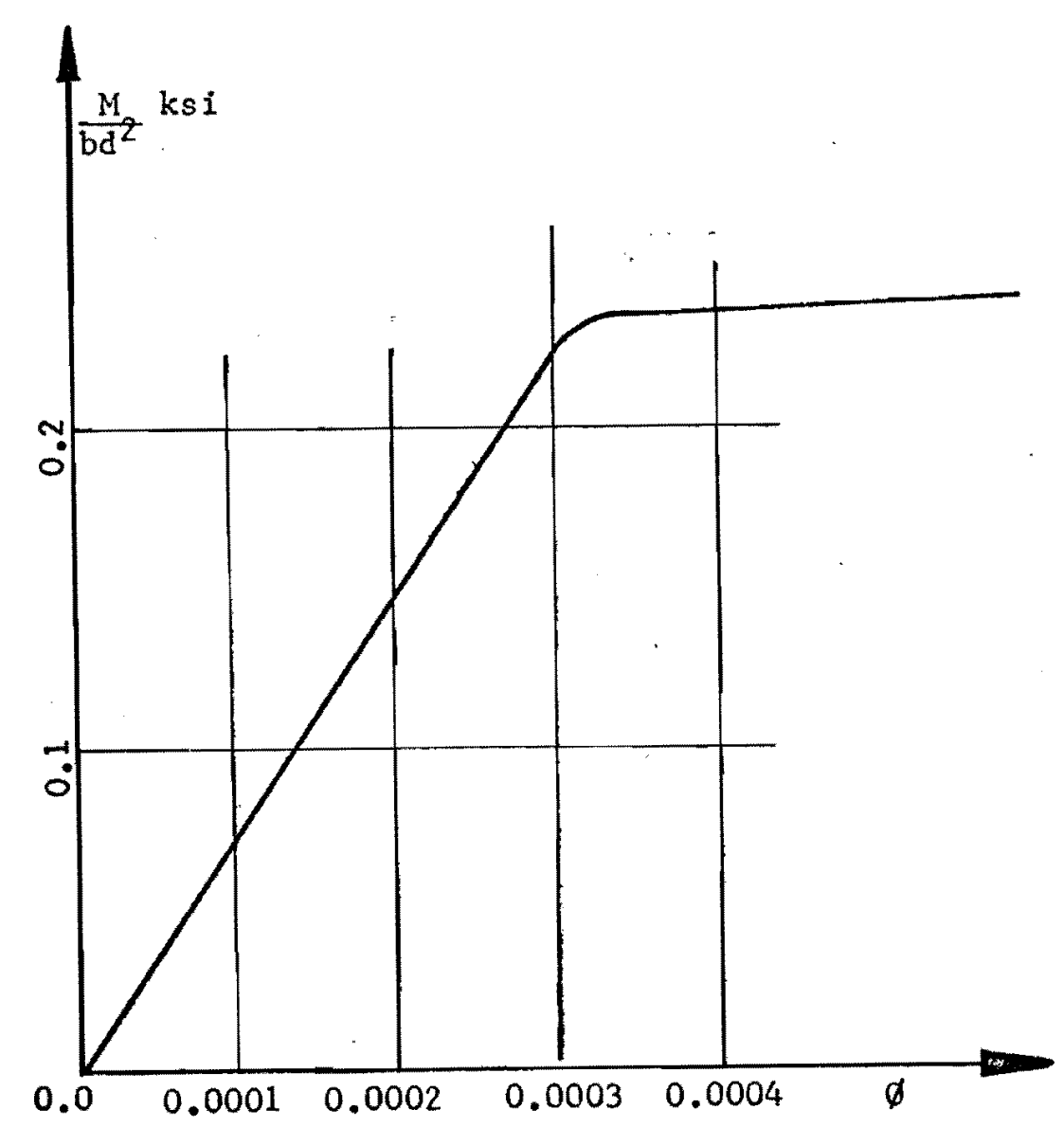

F1g. 5. Typical moment-curvature curve 
3.3 Development of the Theoretical Moment Curvature Relationship

A trial and error method was employed with the aid of an electronic digital computer. The method of solution involved the arbitrary selection of outer fiber tensile strain $\left(E_{S}\right)$ for a given concrete strain $\left(\epsilon_{c}\right)$. Using the stress-strain relationship, tension and compression forces were determined. When these two forces became equal, then it was evident that the right strains were selected. The corresponding $\emptyset$ and $M$ were computed. This operation was repeated for different values of $\varepsilon_{c}$. Finally a moment-curvature curve was determined. The detailed procedure is given in the following section.

\subsection{Computer Ana 1ys is of Moment Curvature}

The program to determine the moment-curvature curve was written in PORTRAN language and was run at the Portland state Unfversity Computer Center on IBM 1130 computer.

For the purpose of analysis the cross-section and the corresponding stress and strain diagrams were divided into a number of rectangles of equal depth. As shown in Fig. 6

a linear strain distribution was assumed.

An Iterative procedure was used for the solution of each point on the moment-curvature. However, an exact solution 1.e., tension force equal to compression force, was not expected to result. Each point was obtained within a predetermined error. To allow a relatively fast convergence in the program, an error limit of one half of one per cent of compression force (C) was taken. 
The program was written for the analysis of flexural members with only tensile reinforctng. The use of different subroutines in the program allows for future modifications with relative ease. The logic diagram of the program, named SOLVE, is given in figures 7 thru 11.

For the complete listing of the program see Appendix.

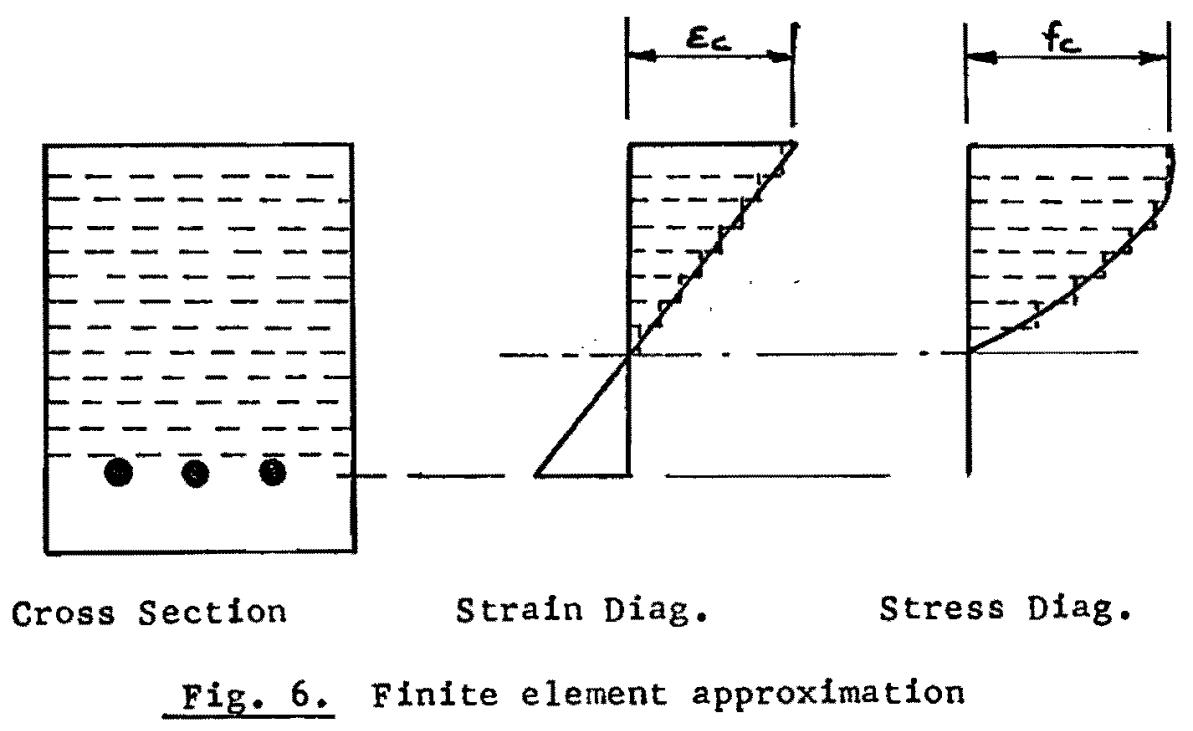




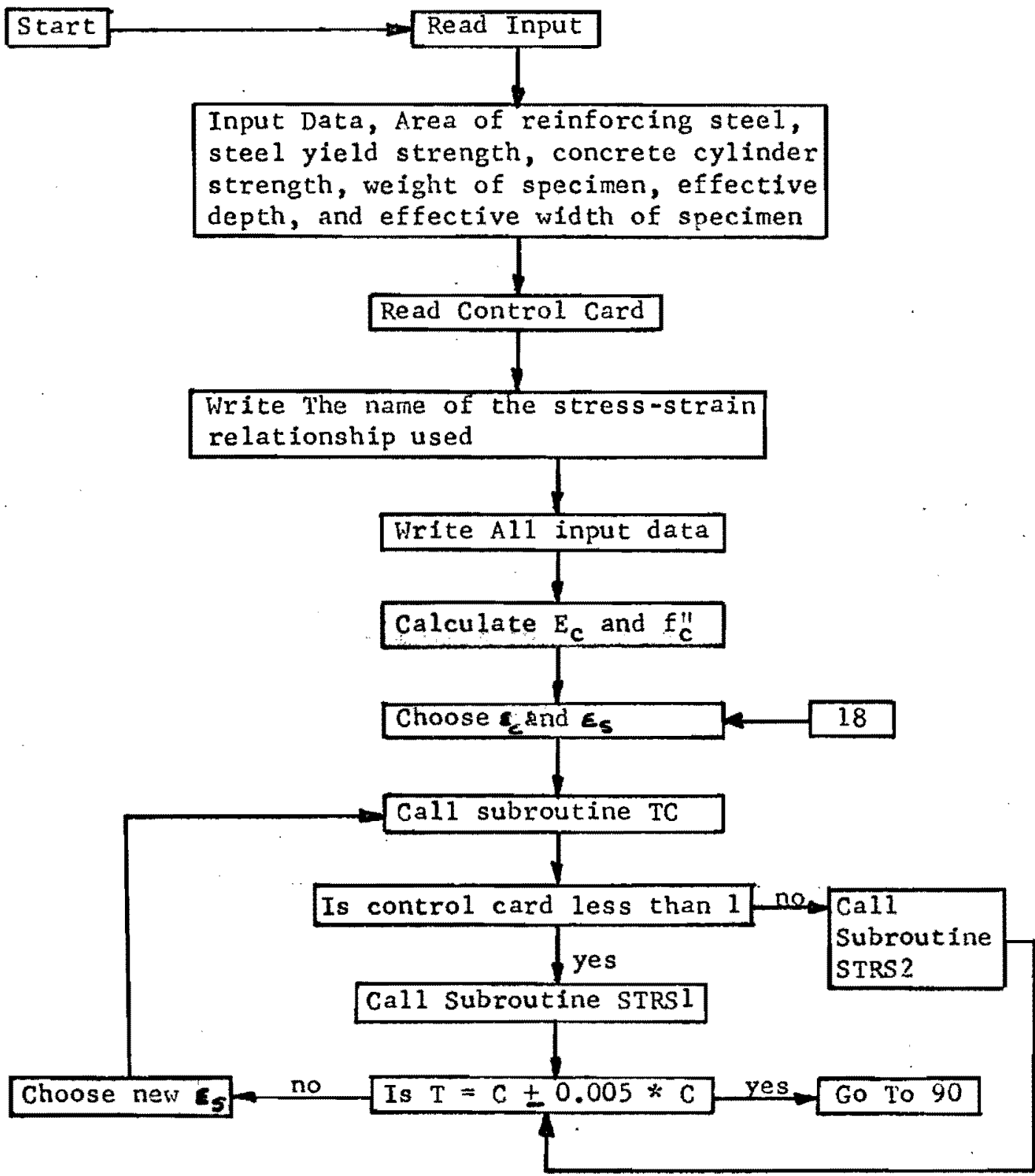

Fig. 7. SOLVE - Logic diagram to calculate tension and compression forces. 


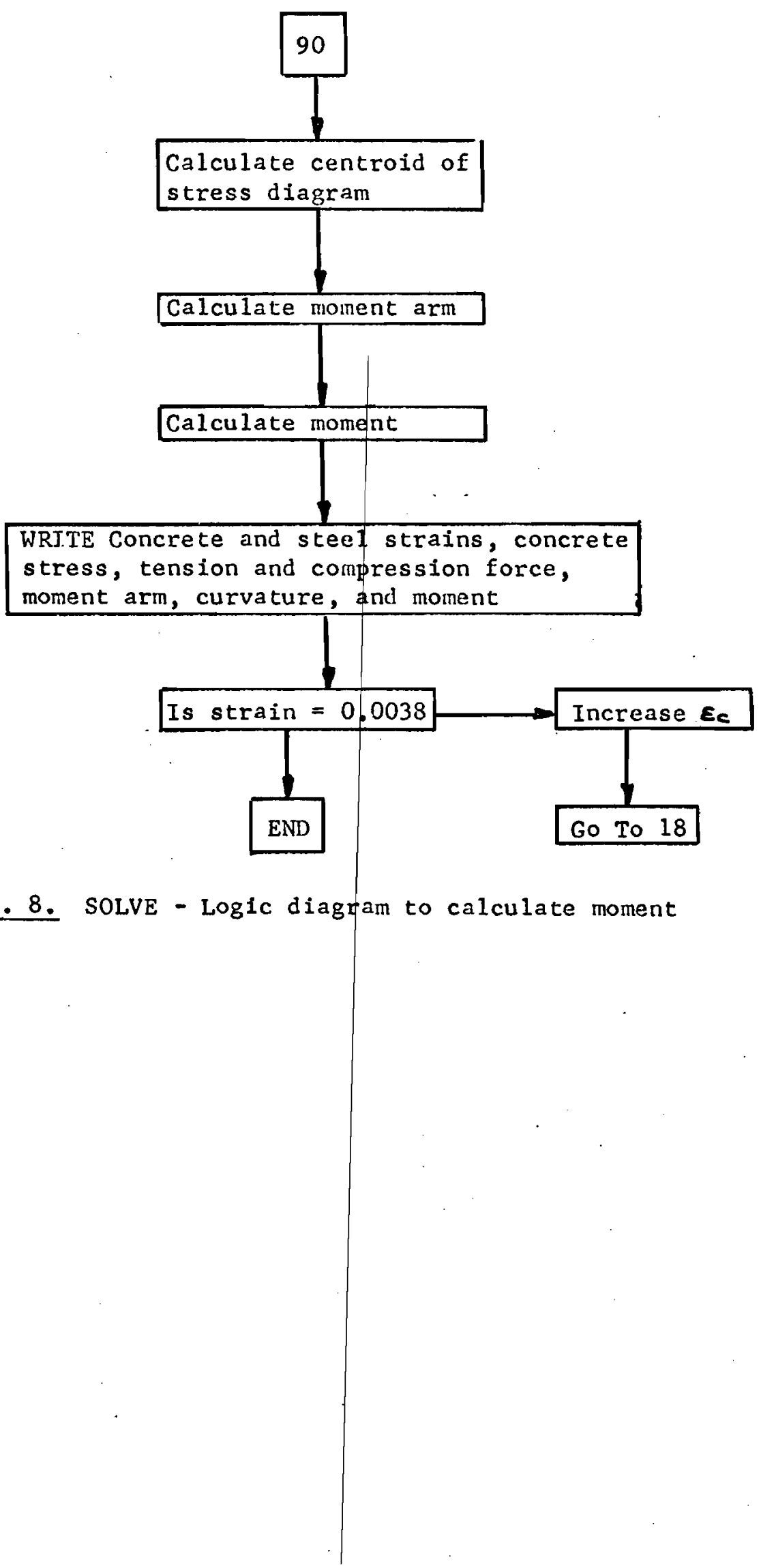




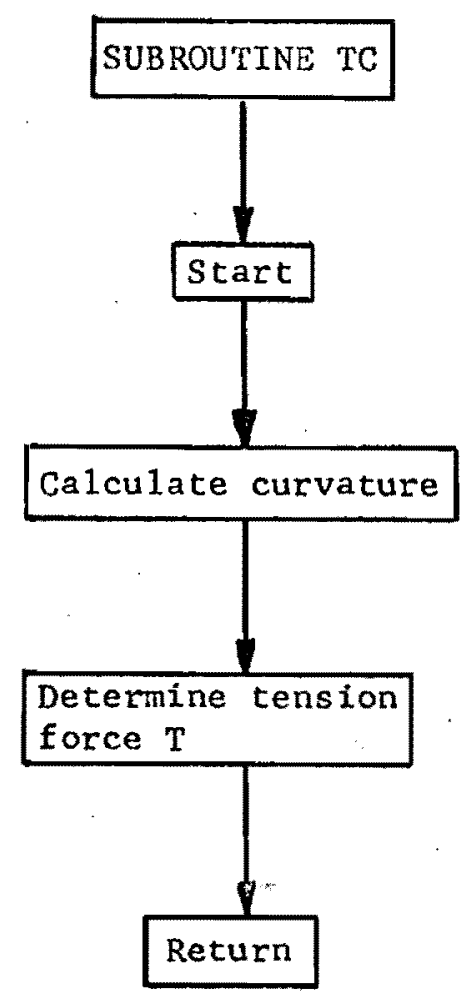

Fig. 9. SUBRoUtine TC - Logic diagram to calculate tension force and curvature. 


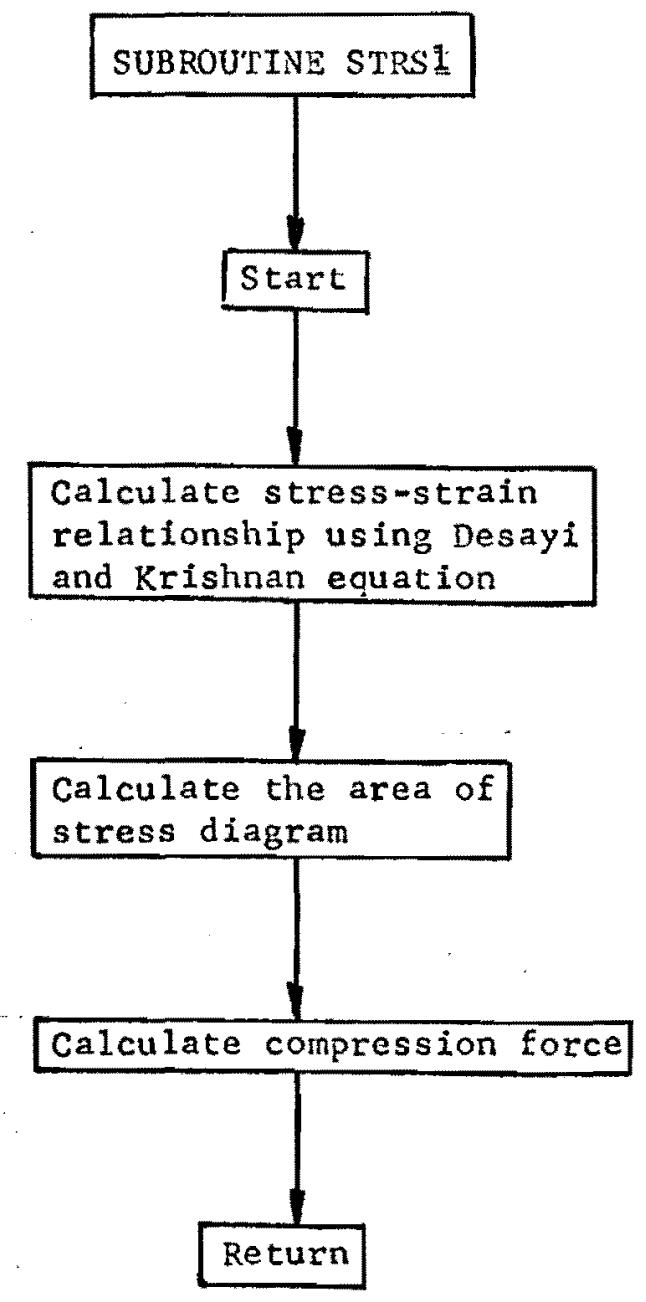

Flg. 10. SUBROUTINE STRS1- Logic diagram to calculate compression force using Desayi and Krishnan stress-strain equation. 


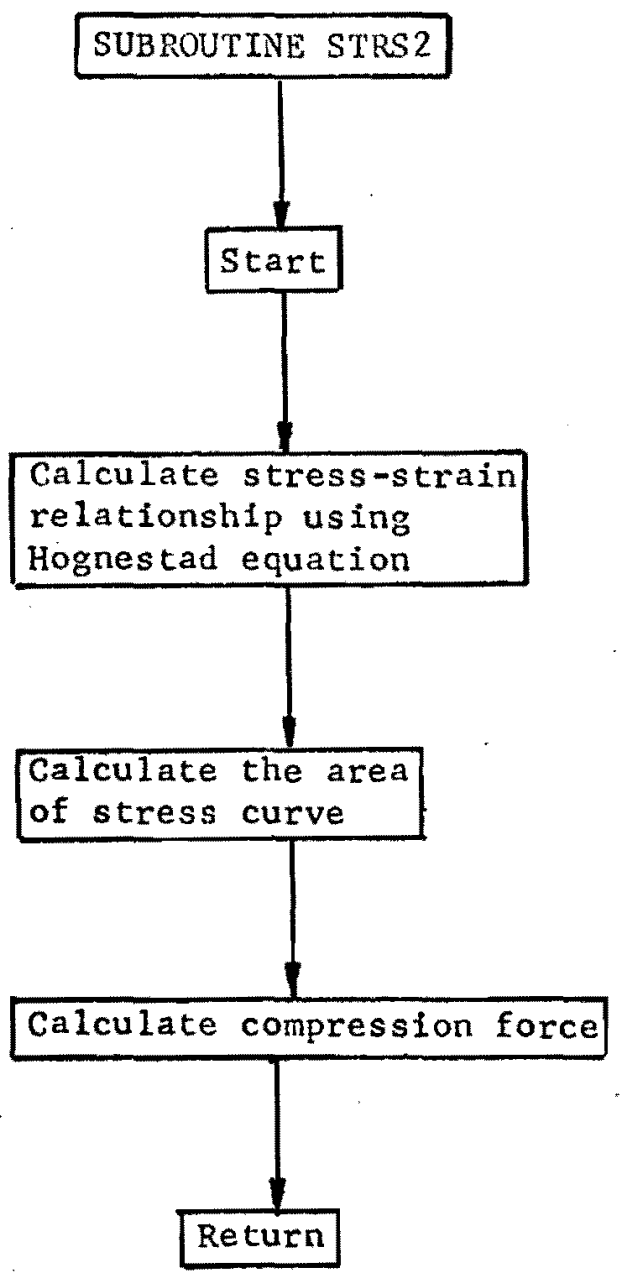

Fig. 11. SUBROUTINE STRS2 - Logic diagram to calculate compression force using Hognestad stress-strain equation. 
CHAPTER IV

MATERIALS, INSTRUMENTATION AND TEST PROCEDURE

\subsection{Reinforcing steel}

All reinforcing consisted of $\# 3$ ( $3 / 8$ inch diameter) bars of high strength deformed steel bars conforming to ASTM A615.

A coupon approximately 18 inches long was cut from each steel specimen. The coupons were tested to failure in a Richle 300 kips testing machine at U. S. Army Corp of Engineers Materlal Laboratory, Troutdale, Oregon. The yield strength of \#3 bars ranged from 69,000 to 70,000 psi.

Reinforcing details are shown in Fig. 12. Specimen $R-1$ and $L-1$ were reinforced with three \#3 bars. The other two specimens were reinforced with two $\# 3$ bars. All reinforcing bars were placed on plastic chairs to secure their vertical position and were tied together by wires to prevent any horizontal movement.

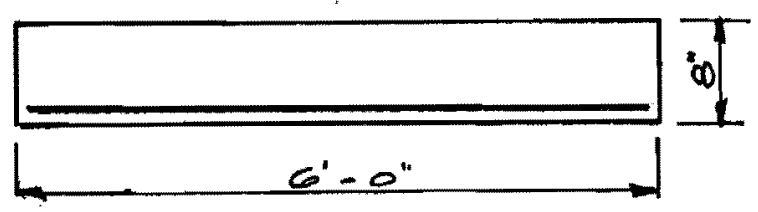

Typica1 Beam Elevation

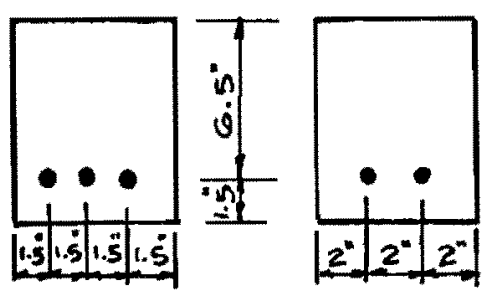

$\mathrm{R}-1 \& \mathrm{~L}-1 \quad \mathrm{R}-2$ \& $\mathrm{L}-2$

Fig. 12. Test specimen details 
4.2 Concrete Materials

A. Normal weight concrete

Oregon Portland Cement Type III (high early strength)

was used. Cement was stored indoors in bags throughout the test.

Coarse aggregate consisted of Willamette River

gravel of $3 / 4$ inch maximum diameter. For fine aggregate, a well

graded Willamette River sand was used.

B. Lightweight concrete

Coarse aggregate consisted of expanded shale, mined near

Banks, Oregon, and produced by a rotary kiln process.

Fine aggregate and cement were the same type used

for normal weight concrete.

The concrete mix was designed to give a seven day cylinder strength of 4500 psi with approximately a two inch slump. The mix data for lightweight and normal weight concrete are shown In tables 1 and 2 .

\subsection{Forms}

Forms were constructed of $3 / 4$ inch exterior plywood, were thoroughly varnished, and were oiled before each use. Careful removal and reassembly allowed the use of one form for al1 four specimens. 
TABLE I

\begin{tabular}{|l|c|r|r|r|r|}
\hline \multicolumn{2}{|c|}{ MIX DESIGN FOR LIGHTWEIGHT CONCRETE TEST BEAMS } \\
\hline MATERIALS & CEMENT & SAND & EXP. SHAL & WATER & TOTAL \\
\hline $\begin{array}{c}\text { WEIGHT } \\
\text { Ib }\end{array}$ & 41.8 & I10.3 & 42.6 & 19.0 & 213.7 \\
\hline \multicolumn{7}{|c|}{ water/cement ratio $=0.455$} \\
\hline
\end{tabular}

TABLE II

\begin{tabular}{|c|r|r|r|r|r|}
\hline \multicolumn{2}{|c|}{ MIX DESIGN FOR NORMAL WEIGHT CONCRETE TEST BEAMS } \\
\hline MATERIALS & CEMENT & SAND & GRAVEL & WATER & TOTAL \\
\hline $\begin{array}{c}\text { WEIGHT } \\
\text { 1b }\end{array}$ & 44.0 & 84.4 & 153.2 & 19.0 & 300.6 \\
\hline \multicolumn{7}{|c|}{ water/cement ratio $=0.432$} \\
\hline
\end{tabular}


4.4 Casting and Curing

A drum type mixer was used. Due to its size, two separate batches had to be made in order to cast one beam and six $6 \times 12$ standard cylinders. Special care was taken to make the two batches as nearly identical as possible. Three standard 6 X 12 test cylinders from. each batch vere cast in steel forms and were thoroughly compacted by hand tapping.

The concrete beams were placed in two lifts with each lift thoroughly compacted by hand tapping and by means of a $13 / 8$ inch diameter vibrator head. After casting, exposed surfaces of all specimens were given a smooth finish with a steel hand trowel.

The test specimens and the test cylinders were kept moist and covered with a waterproof sheet for 24 hours after casting. When forms were removed, the specimens were moist cured until two days prior to testing.

\subsection{Specimen Dimensions}

Since no over-head crane was available in the laboratory, the weight of the test beams was a controlling factor in the size of the specimens. The width of beams were chosen to assure a flexural failure. Fig. 12 shows test specimen details.

\subsection{Testing Equipment and Instrumentation}

The test beams were loaded as shown in Fig. 13. The concentric load $P$ was applied to a $100 \mathrm{kip}$ capacity load cell 


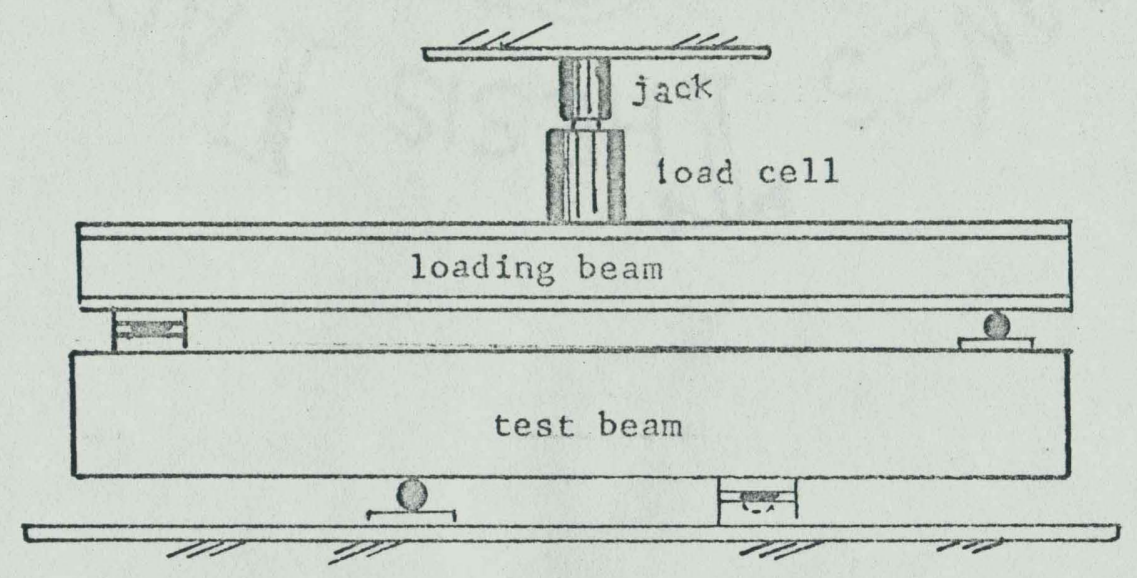

Fig. 13. Typical loading for test specimens

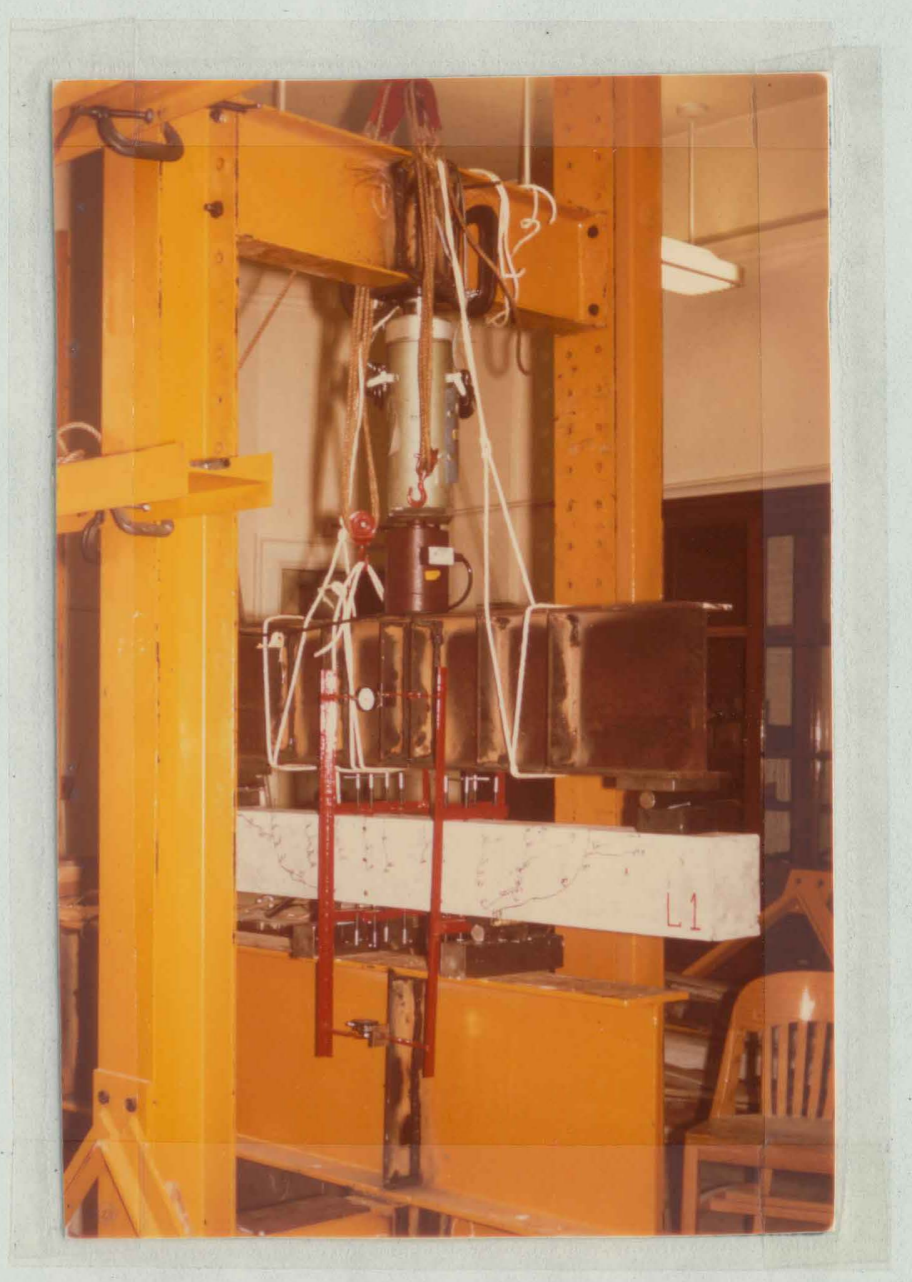

F:-5. 14. Typical test set up 
by means of a simplex hand operated hydraulic pump and ram arrangement. Fig. 14 shows the testing frame and a typical test set up.

To facilitate observation of the tensile face of the beam, It was tested upside down. The applied load was recorded from a Daytronic Model 711 dlal indicator connected to the load cell.

The point loads and roller supports were simulated by use of steel rollers and base plates (Fig. 15). The supports were placed approximately six inches from each end of the beam, thus reducing the span length of the beam to exactly five feet. The concrete strain was measured by dial gauges attached at top and bottom of the rotation bars. These bars were fabricated from steel angles and were placed at each side of the test specimen (Fig. 14).

\subsection{Test Procedure}

All loads were applied at 0.5 to $1.0 \mathrm{kip}$ increments. After each loading increment, dial gauges were read and recorded. During the testing operation for two specimens (R-1 and $R-2)$ some mis-alignment was noticed. In such instances, the loads were reduced to the starting point and after correction was made the test operation was resumed. 


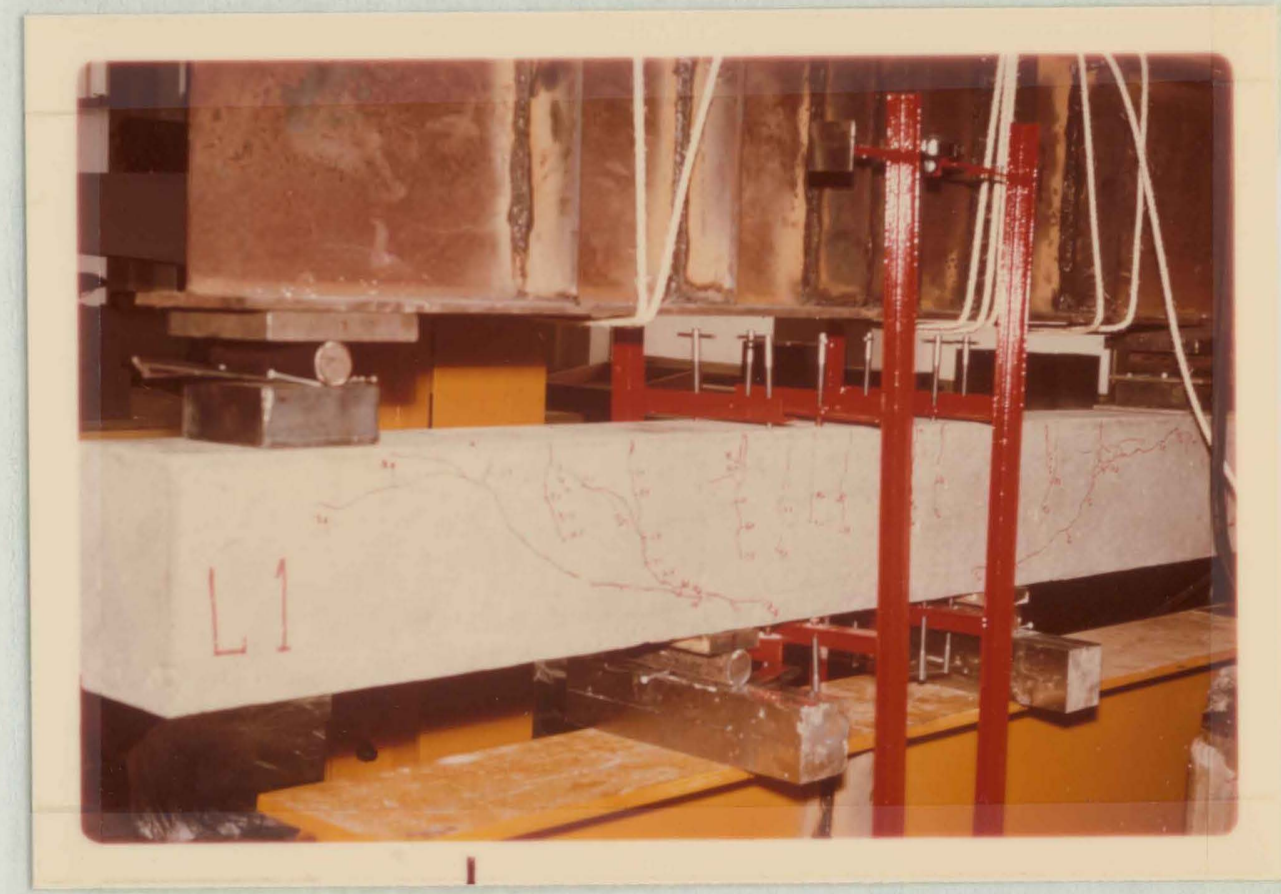

Fig. 15. Typical test beam roller supports 


\section{CHAPTER V}

\section{ANALYSIS OF TEST DATA AND CONCLUSION}

\subsection{Curvature}

The curvature of test beams was determined by the use of rotation meters. The placement of rotation bars at each side of the specimen provided two curvature values for each load increment. The average of the two curvature values were used in the analysis. The method of calculation is outlined below.
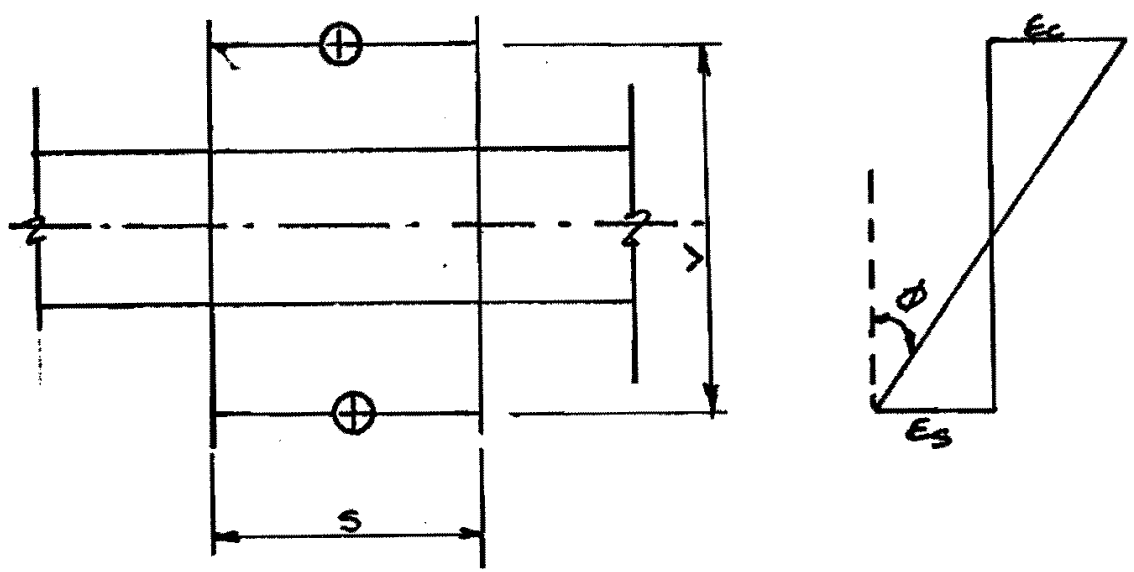

Fig. 16. Calculation of experimental curvature

For one inch unit

$$
\phi=\frac{\left[\varepsilon_{c}\right]+\left[\varepsilon_{\delta}\right]}{S \times V}
$$

Where $S=$ horizontal distance between rotation bars

$$
V=\text { vertical distance between dial, gauges }
$$


5.2 Moment

Figure 17 shows the loading, shear, and moment diagrams.

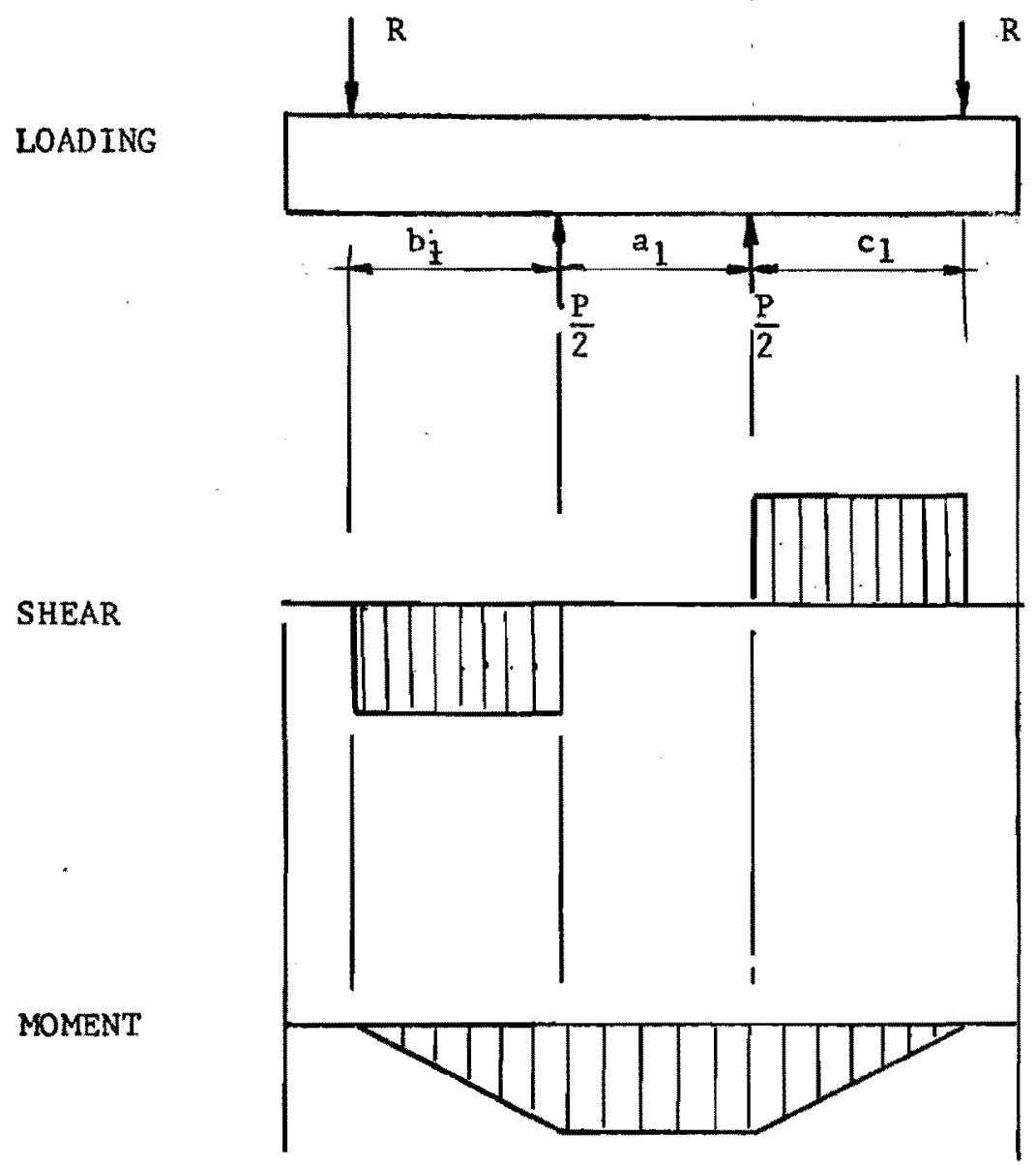

Fig. 17. Typical loading, shear, and moment diagrams

Since the maximum variation in the length $a_{1}, b_{1}$, and $c_{1}$ was only $1 / 8$ of an inch, then they were assumed equal and the maximum moment was simply calculated as $\frac{\mathrm{PL} \text {. }}{6}$ 


\subsection{Failure characteristics}

The first visible tension cracks occured generally about $1 / 5$ of the ultimate applied load. As the load was increased, the depth of the cracks became vistble at the ends of the specimens. Lightweight concrete specimens developed large shear cracks before failure, but in the nornal weight specimens the failure occured by the extension of tension cracks into the compression zone (Figs, 18 and 19).

It should be noted that the test beams were not loaded to complete failure. Loading was stopped at the point where the load dial indicator would not advance with additional pumping of the jack. This procedure provided additional safety protection to the personnel and the equipment.

\subsection{Test Analysis}

Due to the tension resistance of concrete, the infial portion of the experimental moment-curvature curves shows a higher slope compared to that of theoretical results. This is because the theoretical $M-\varnothing$ curves are developed with the assumption that concrete section is cracked and does not carry any tension. The computer program used to develop the theoretical moment-curvature relationship can be modified to incorporate the tension strength of concrete with that of reinforcing steel. This would give a somewhat closer comparison between the experimental and the theoretical results.

After the initial rise, the experimental results approach the 


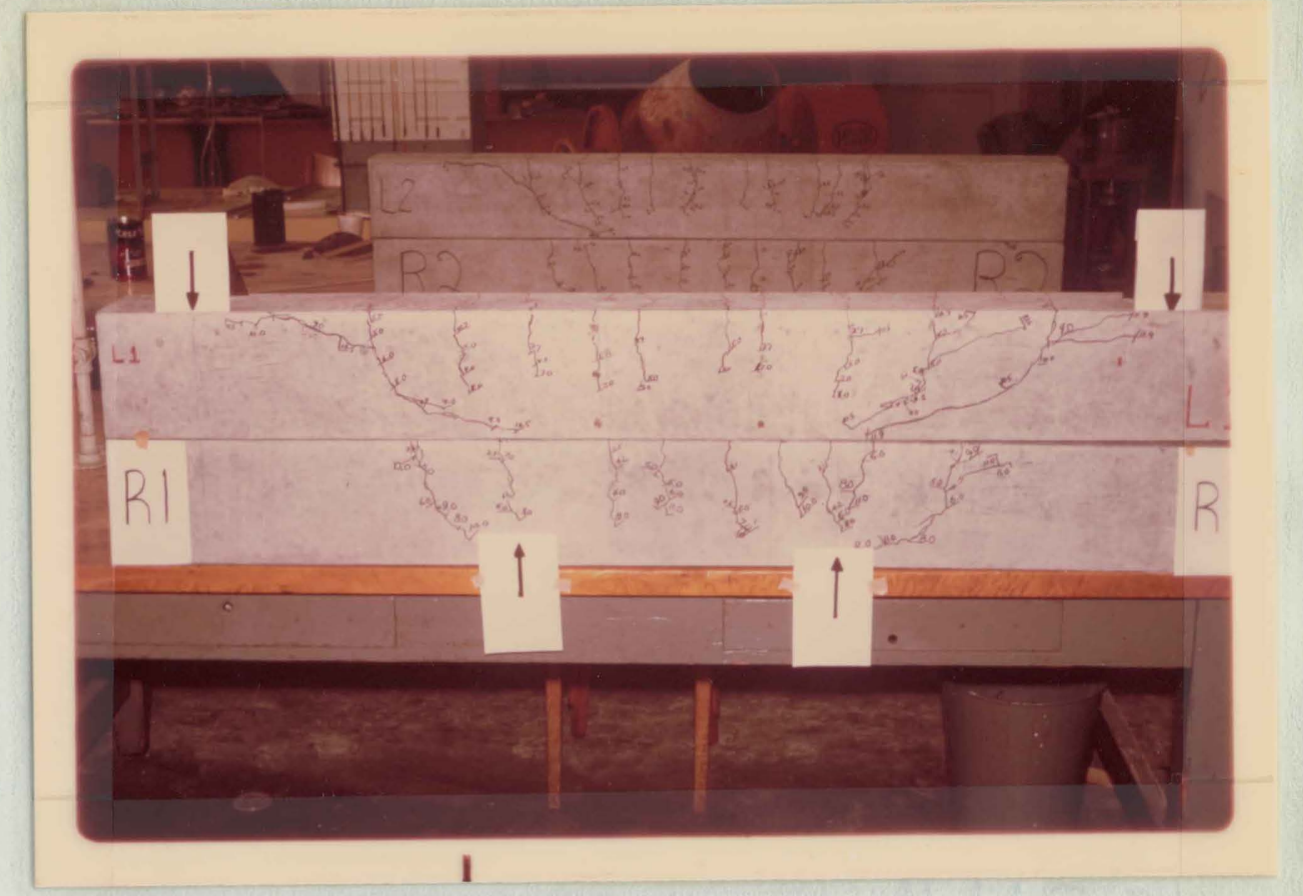

Fig. 18. Specimen $\mathrm{R}-1$ and $\mathrm{L}-1$ after test was completed.

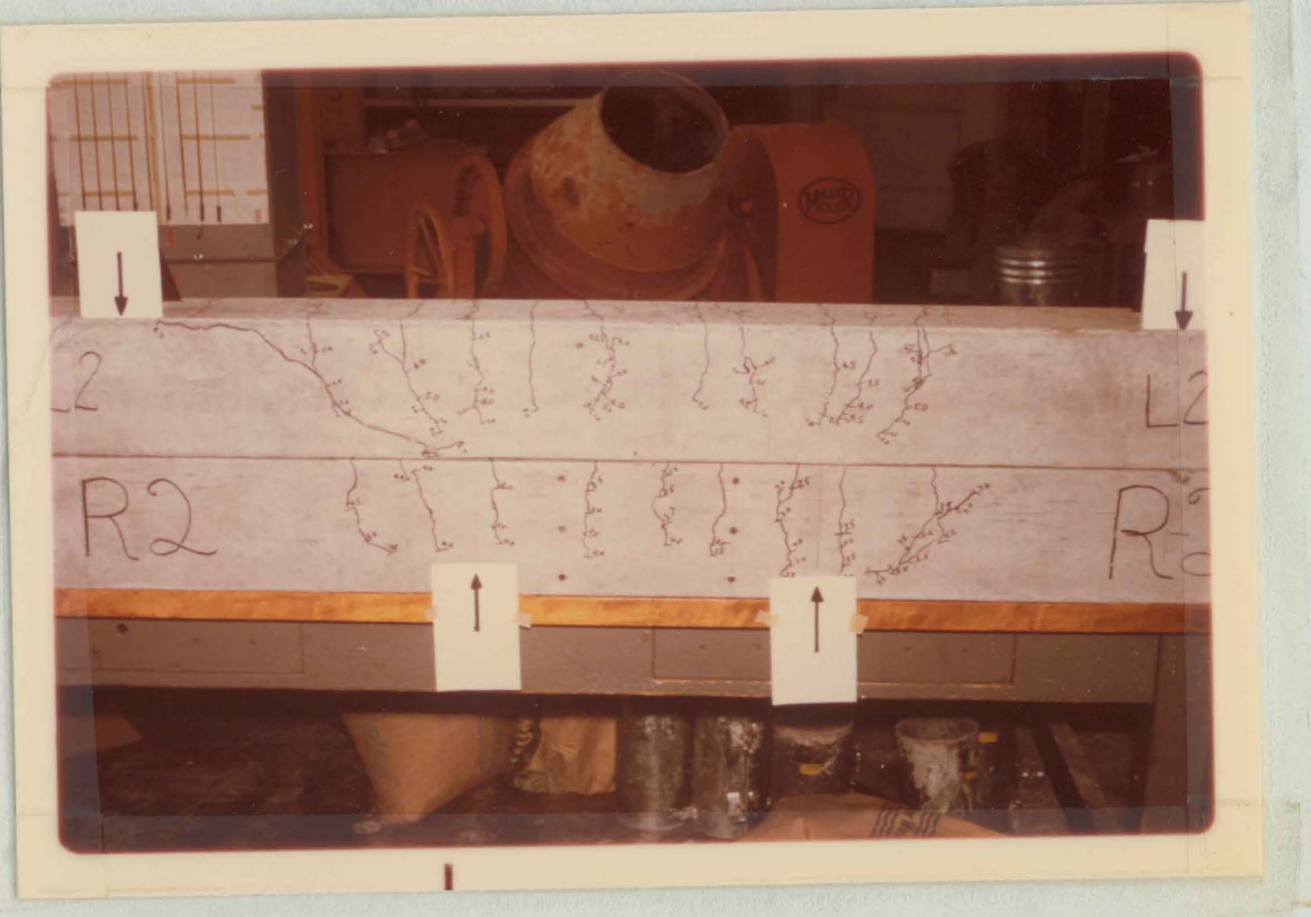

Fig. 19. Specimen $R-2$ and $L-2$ after test was completed. 
theoretical curve, cross it, and drop to just below the ultimate moment. Figs. 20 thru 27 show the theoretical and the observed $M-\varnothing$ curves for the test beams.

Test specimens $(R-1$ and $R-2)$ compared to ( $L-1$ and $L-2)$ had a somewhat higher (about $6 \%$ ) compressive cylinder strength. However, this small variation in $f_{c}^{1}$ had a very small effect on the $M-\varnothing$ curves. Therefore it was ignored.

Both the lightweight concrete test beams ( $L-1$ and $\mathrm{L}-2$ ) show comparable ultimate moment to that of normal concrete beams $(R-1$ and $R-2)$. However, as can be seen from Figs. 20 thru 27 the lightweight concrete specimens developed much higher deflection.

Lightweight concrete used in this study (1ightweight aggregate and natural sand) had a lower unit weight (about $27 \%$ of normal weight concrete). This unit weight reduction, assuming all other parameters to be equal, would result in a more economical structure.

\subsection{Conclusions}

Based on this limited study the following conclusions seem warranted.

1. Lightweight concrete and normal weight concrete test beams show comparable moment capacity (about $92 \%$ of normal welght concrete).

2. Under the same loading conditions, lightwelght concrete compared to normal weight concrete gives a larger deflection (about 40\% more than normal weight concrete). 
3. The lower unit weight of concrete, assuming all other parameters to be equal, would result in a more economical structure.

4. A generalized computer program to determine the momentcurvature relationships of a singly reinforced rectangular concrete beam was developed. This computer program could be used with different stress-strain relationships by simply replacing the appropriate subroutine.

5. The computer program developed here-in can be easily modified for different shapes of cross sections. Similarly, it can be adopted to include the tensile stress-strain characteristics of concrete. 


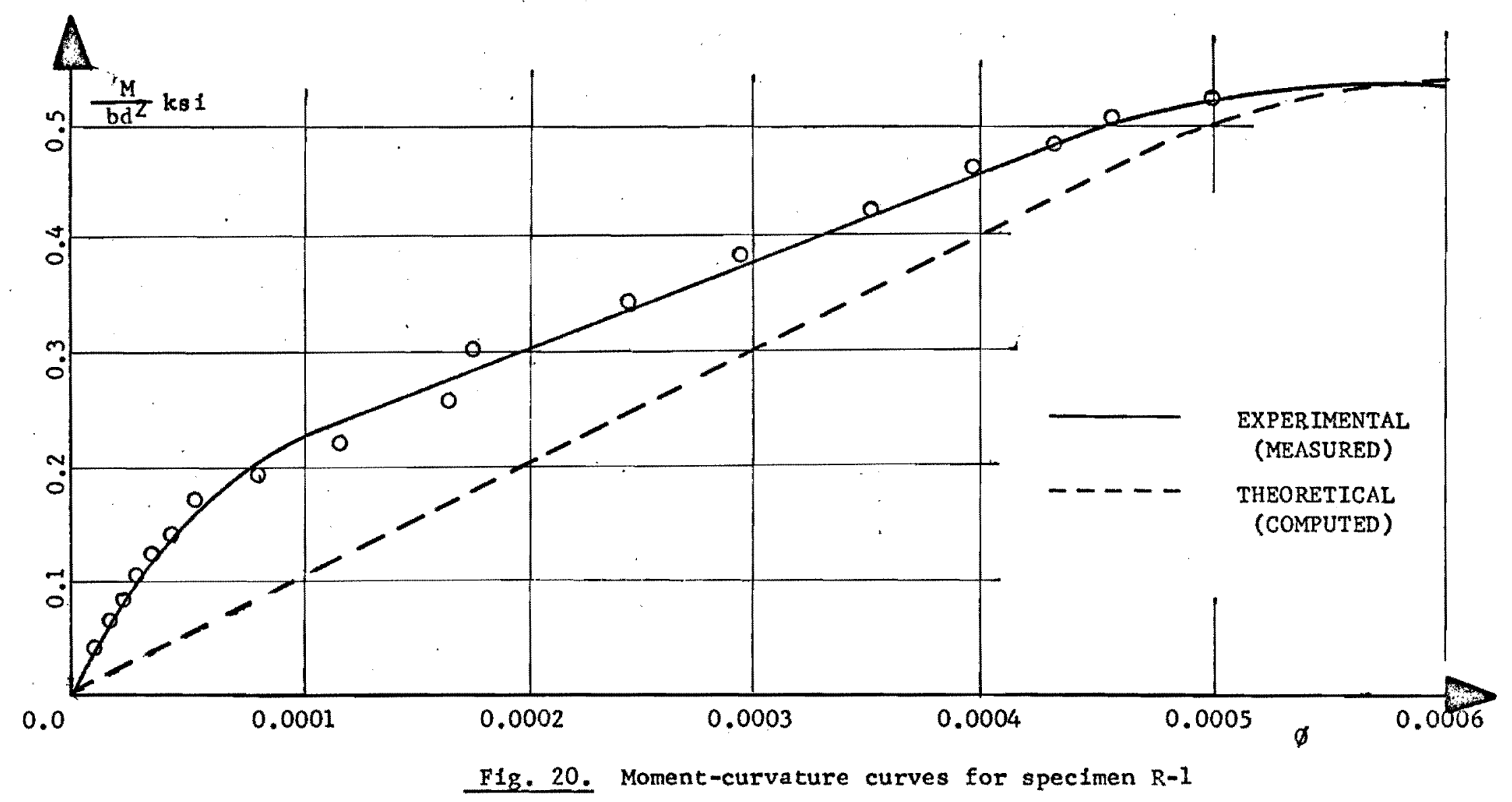




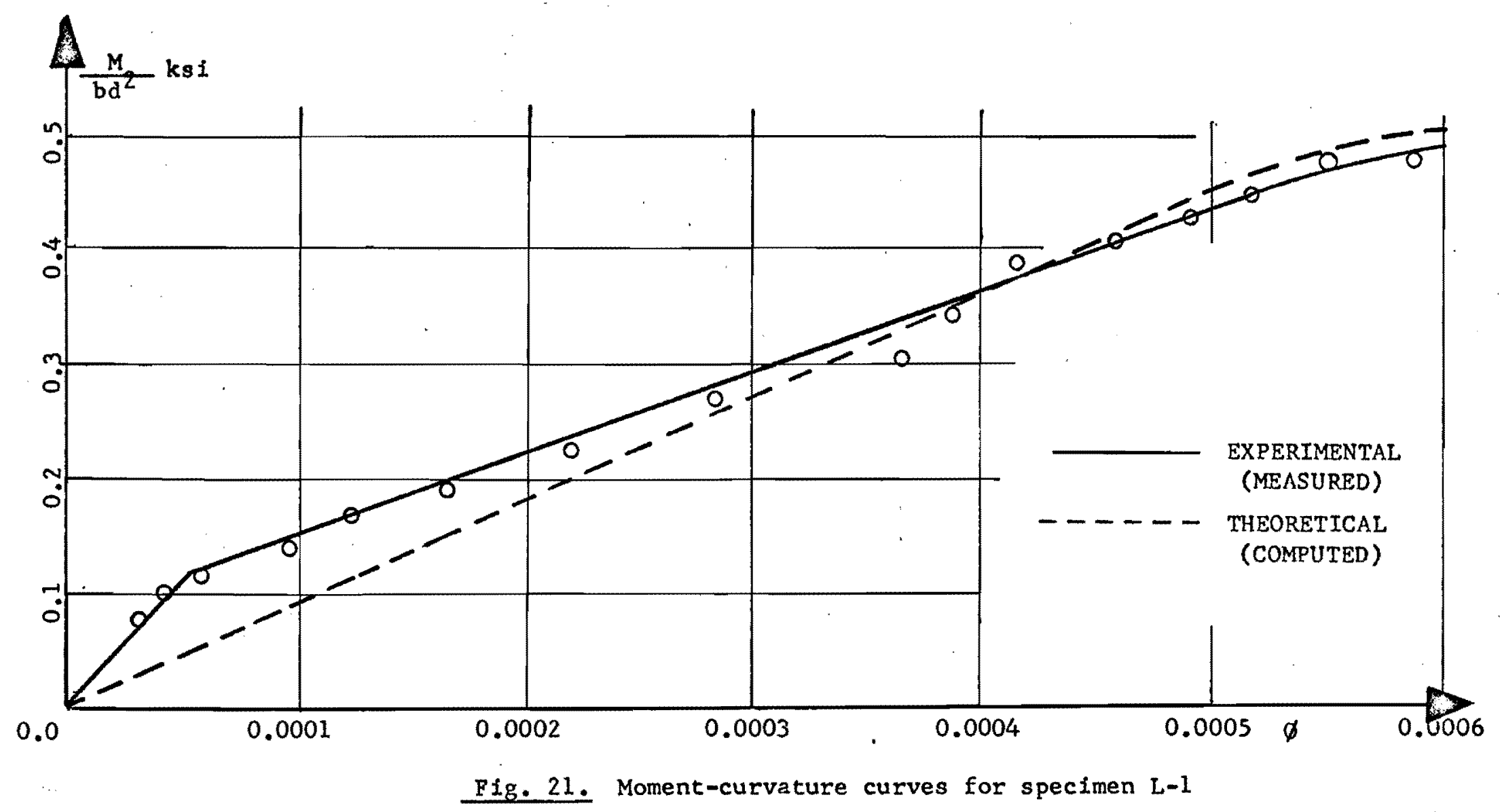

$\stackrel{w}{ }$ 


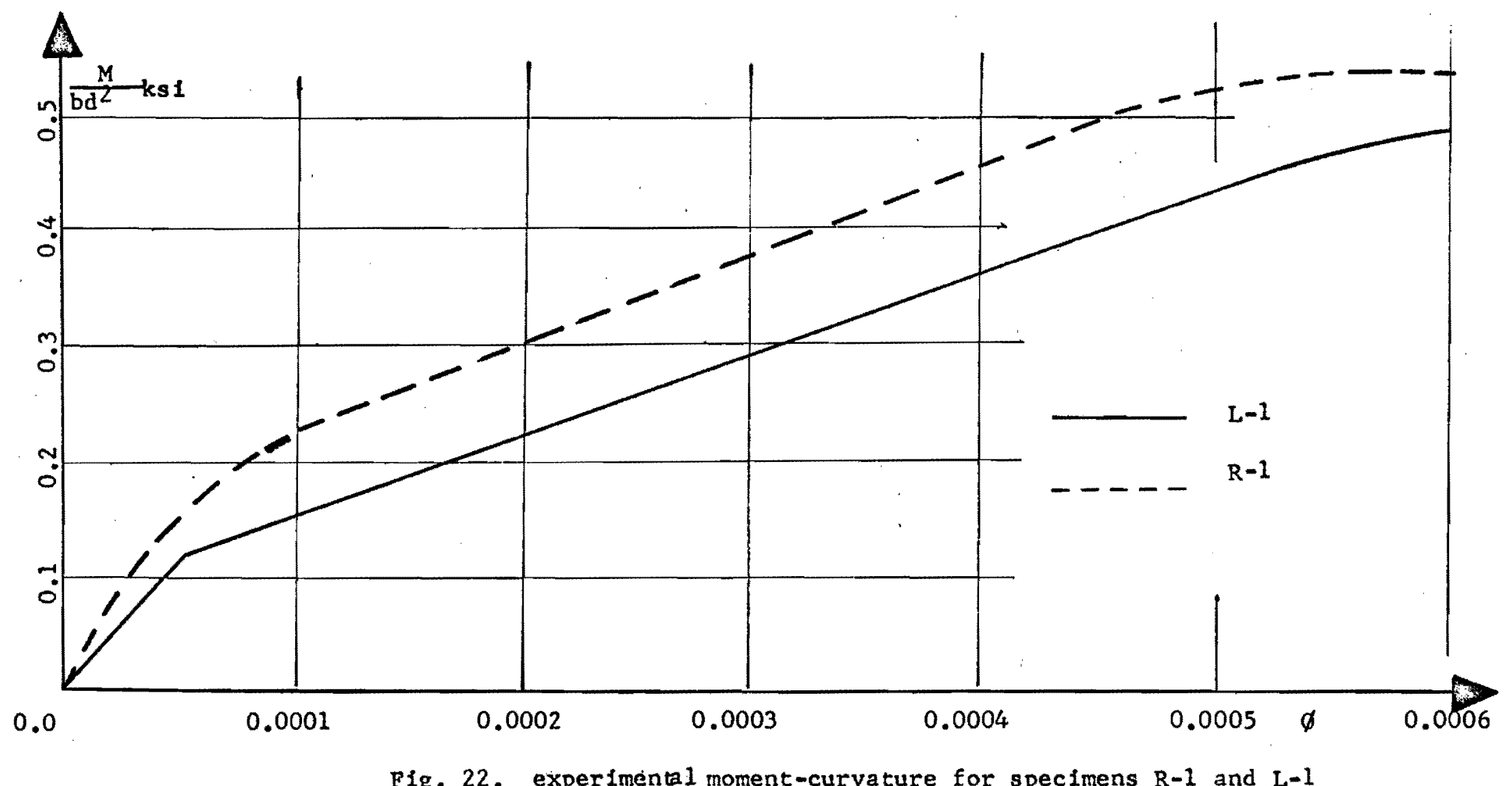

Fig. 22, experimental moment-curvature for specimens $R-1$ and $L-1$ 


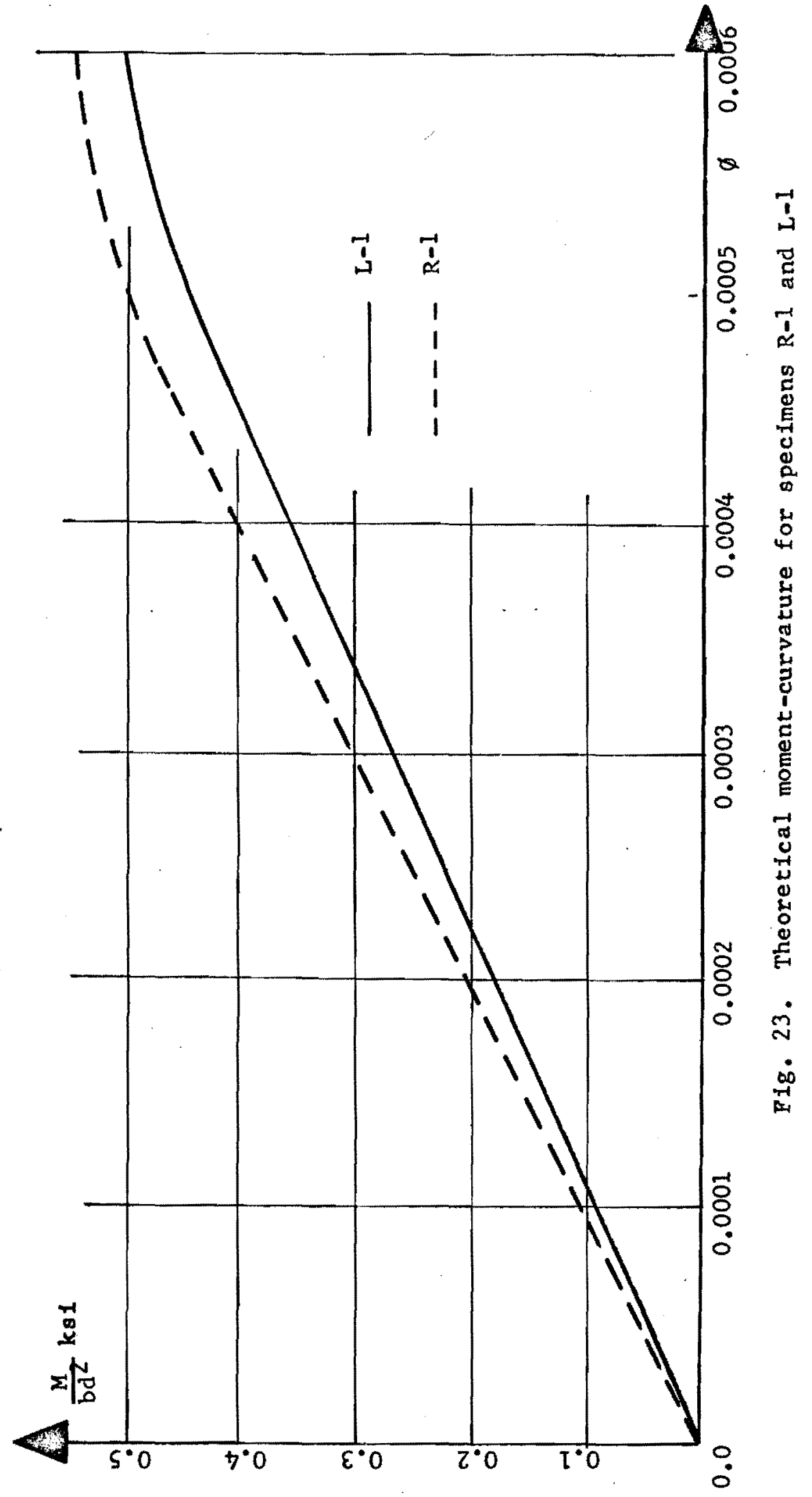




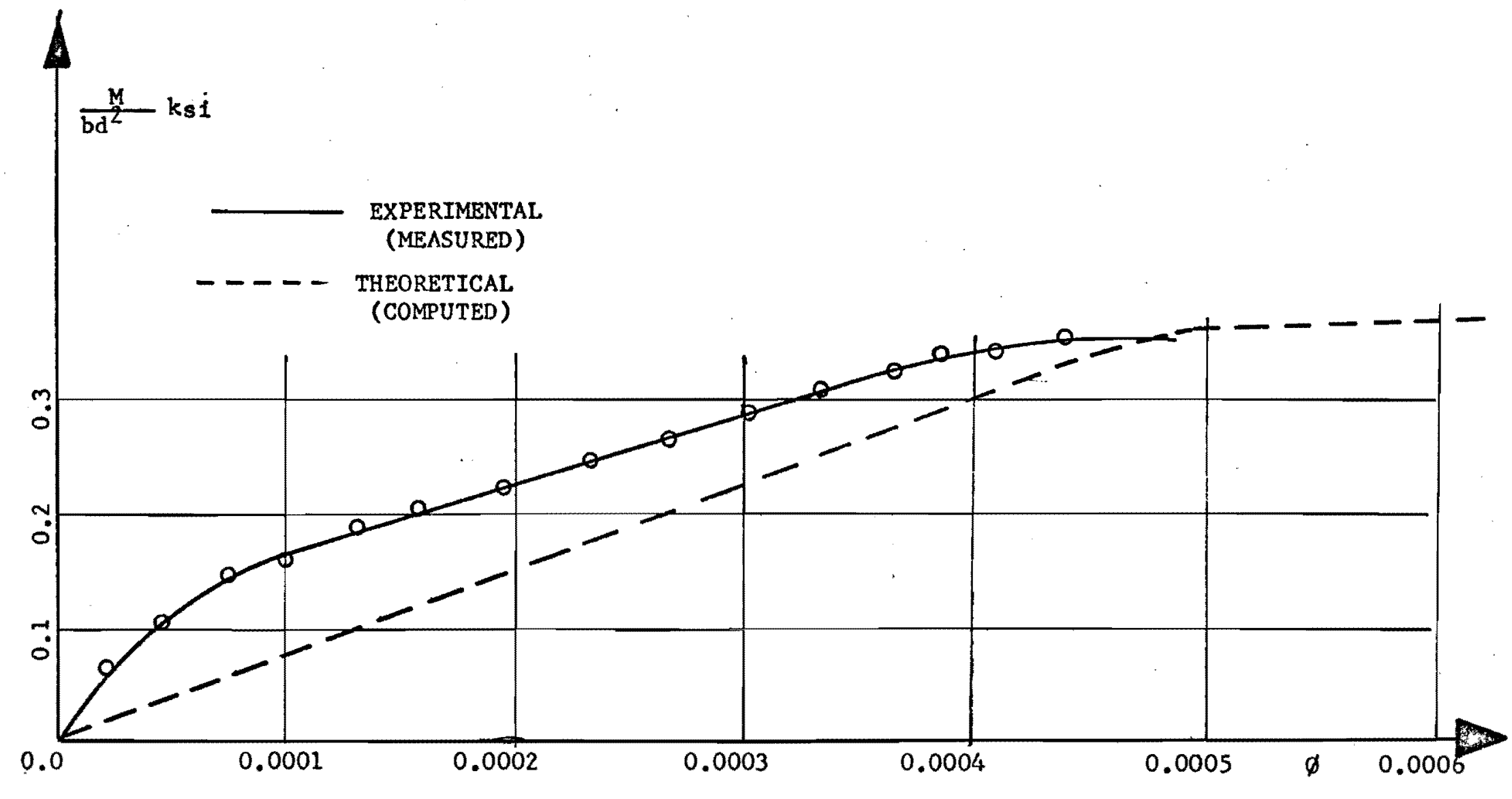

F1g. 24. Moment-curvature curve for specimen R-2 


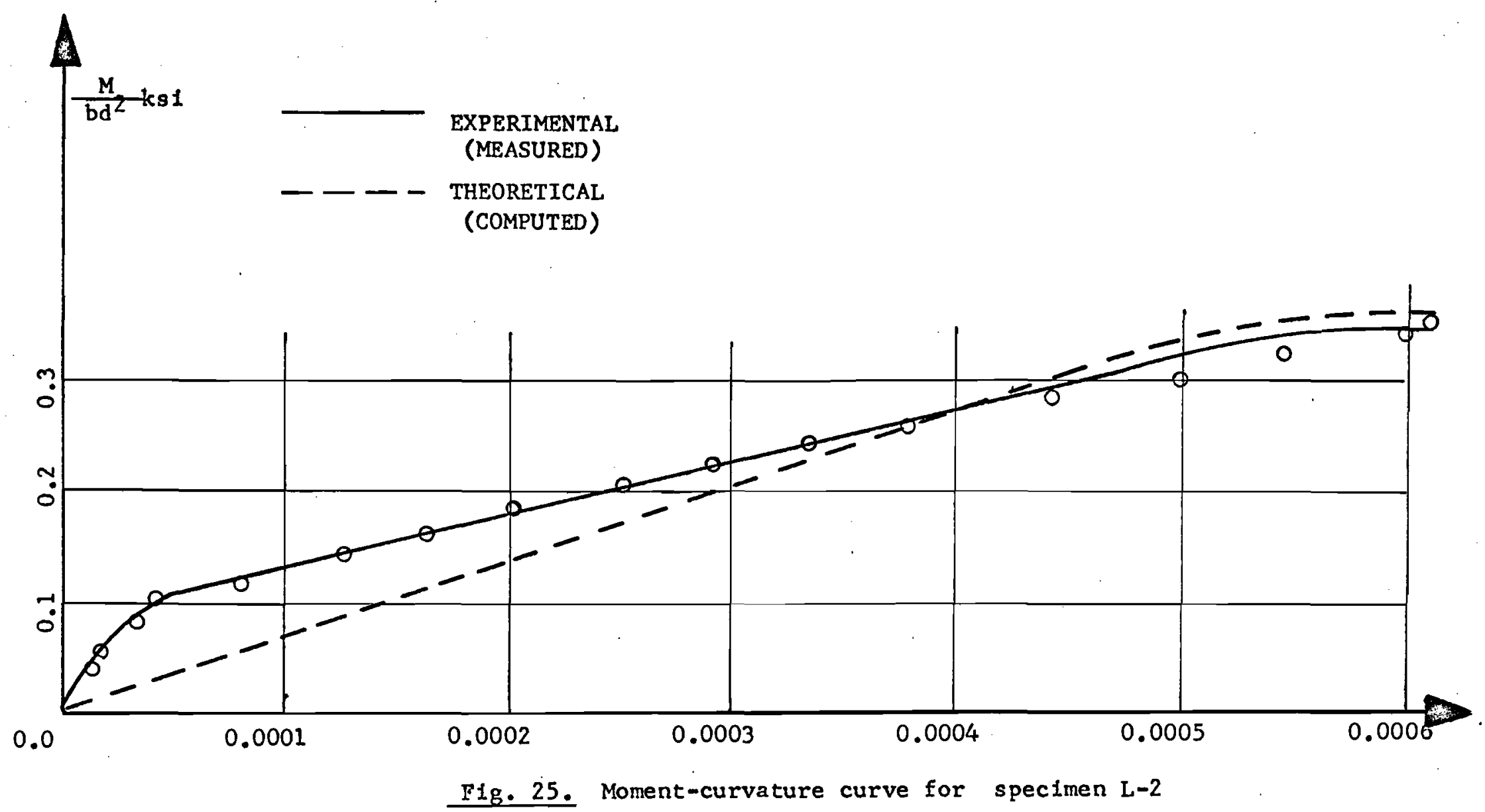




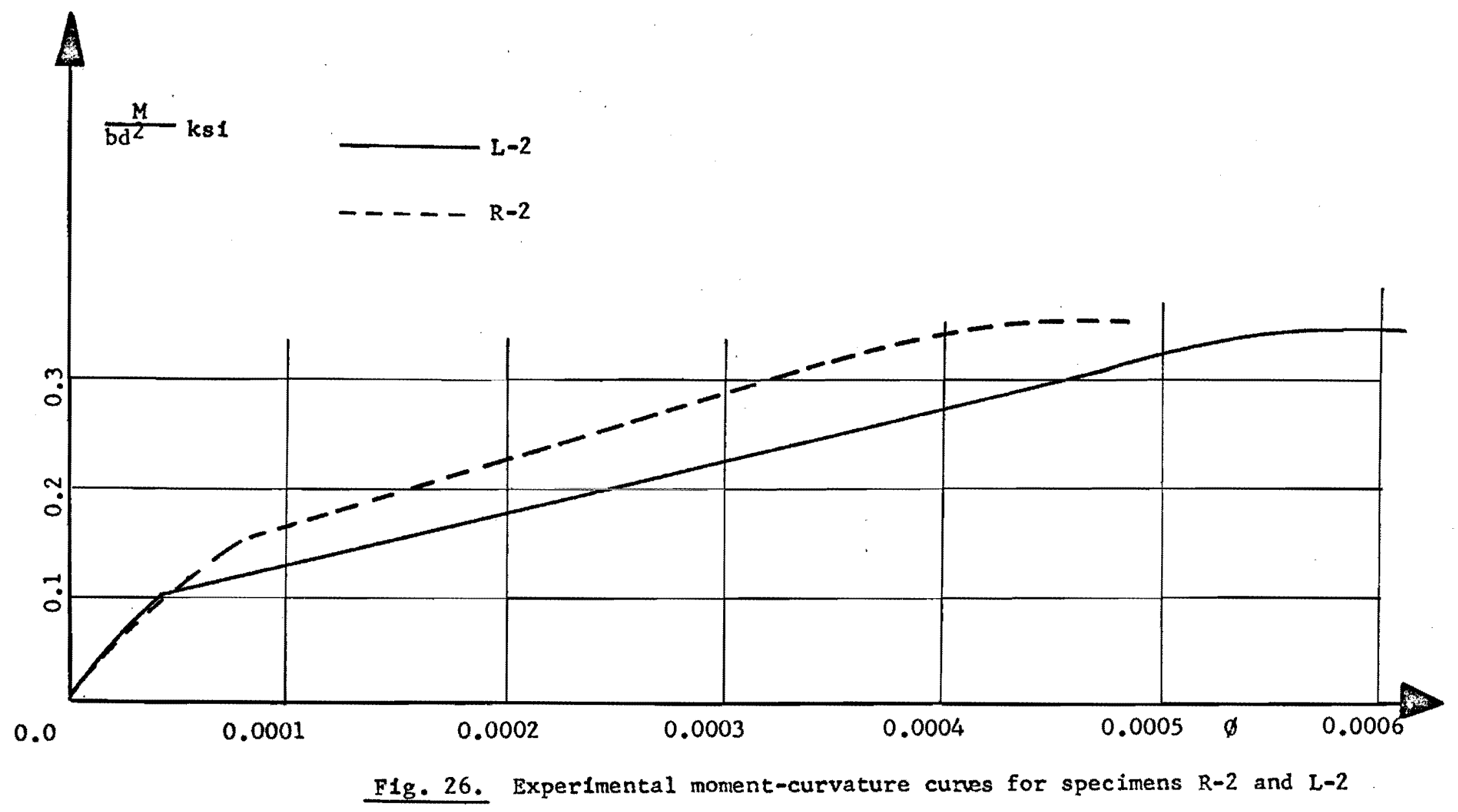




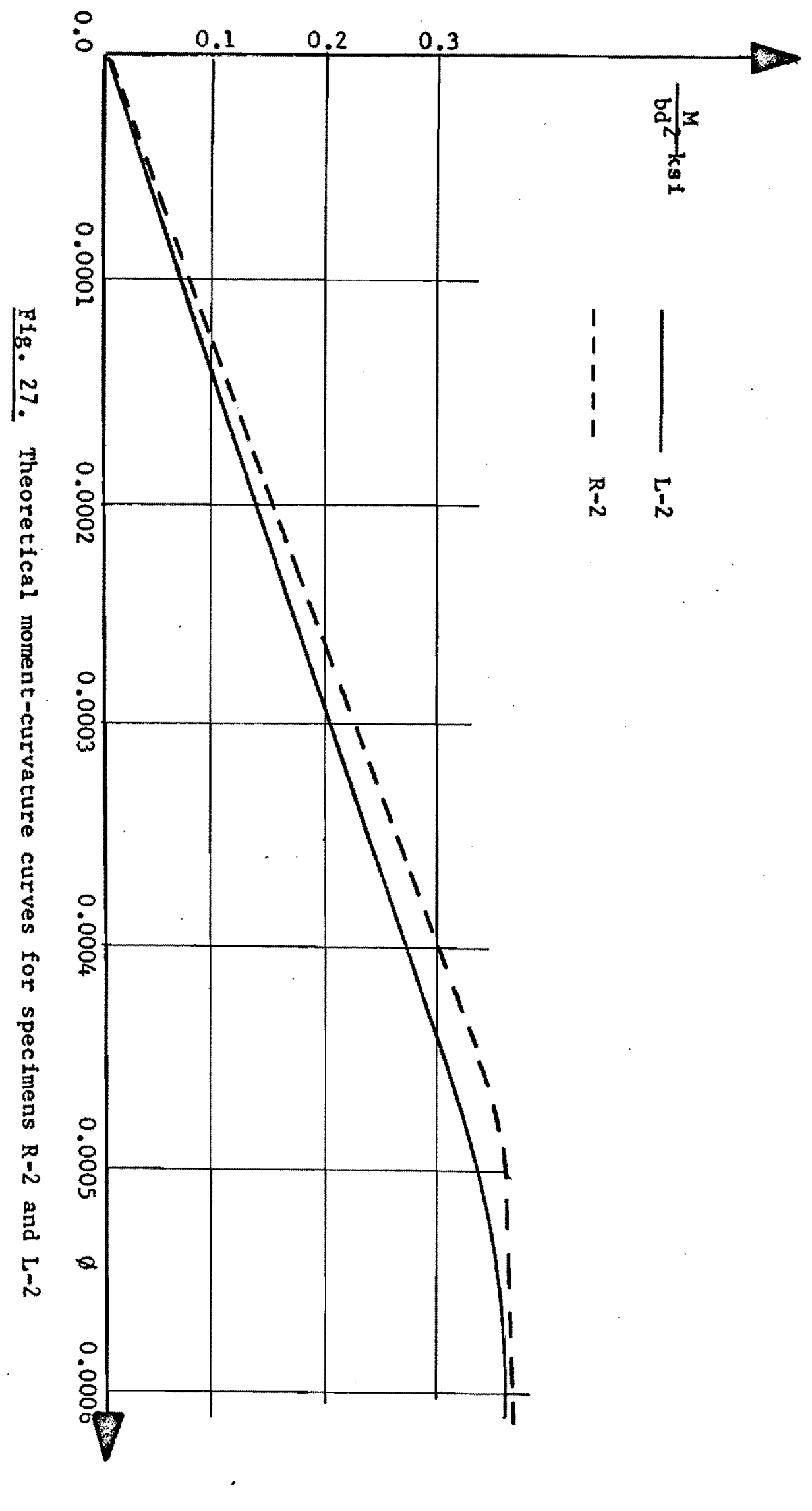


REFERENCES

1. Popovics, S., "A Review of Stress-Strain Relationship for Concrete," Journal American Concrete Institute Proceeding, Vol. 67, March 1970, Pp. 243-248.

2. Ghosh, S. K., Discussion of "A Review od Stress-Strain Relationship for Concrete," by S. Popovics, Journal American Concrete Institute Proceeding, Vol. 67 , Sept. 1970 p. 753.

3. Desayi P., and Krishnan, S., "Equation for the Stress-Strain Curve of Concrete," Journal American Concrete Institute Proceeding, Vol. 61, March 1964, PP. 345-350.

4. Kabaila, A., Saenz, L. P., Tulen, L. G., and Gerstle, K. H., Discussion of "Equation for the Stress-strain Curve of Concrete," by P. Desayi and S. Krishnan, Journal American Concrete Institute Proceeding, Vol. 61, Sept. 1964, PP. 1227-1239.

5. Shideler, J. J., "Manufacture and Use of Lightweight Aggregates for Structural Concrete," PCA Development Department Bulletin D40, Jan. 1961, PP. 1-19.

6. American Concrete Institute Committee 213, "Guide for Structural Lightweight Aggregate Concrete," Journal Anerican Concrete Institute Proceeding, Vol. 64, Aug. 1967, PP. 433-467.

7. "Lightweight Aggregate Concrete," Housing and Home Finance Agency, Washington, D. C., August:1949.

8. "Lightweight Aggregate for Concrete," Expanded Shale, Clay, and Slate Institute, Washington, D. C., Bulletin 36.

9. Shideler, J. J., "Lightweight Aggregate Concrete for Structural Use," Journal American Concrete Institute Proceeding, Vol. 54, oct. 1957, Pp. 299-238.

10. Jenny, D. P., "Unique Problems in Concrete," Expanded Shale, Clay, and Slate Institute, Washington, D. C., March 1963.

11. Pauw, A., "Static Modulus of Elasticity of Concrete as Affected by Density," Journal American Concrete Institute Proceeding, Vol. 57, Dec. 1960, pp. 679-687. 
12. Hanson, J. A., "Shear Strength of Lightweight Reinforced Concrete Beams," Journal American Concrete Institute Proceeding, Vol. 55, Sept. 1958, pp. 387-403.

13. Hanson, J. A., "Tensile Strength and Diagonal Tension Resistance of Structural Lightweight Concrete," Journal American Concrete Institute Proceeding, Vol. $58, \mathrm{July}$ 1961, pp. 1-39.

14. Hognestad, E., "A Study of Combined Bending and Axial Load in Reinforced Concrete Members," University of Illinois Engineering Experiment Station Bulletin, Series No. 399, 1951 . 
APPENDIX

\section{LISTING FOR THE COMPUTER PROGRAM - SOLVE}

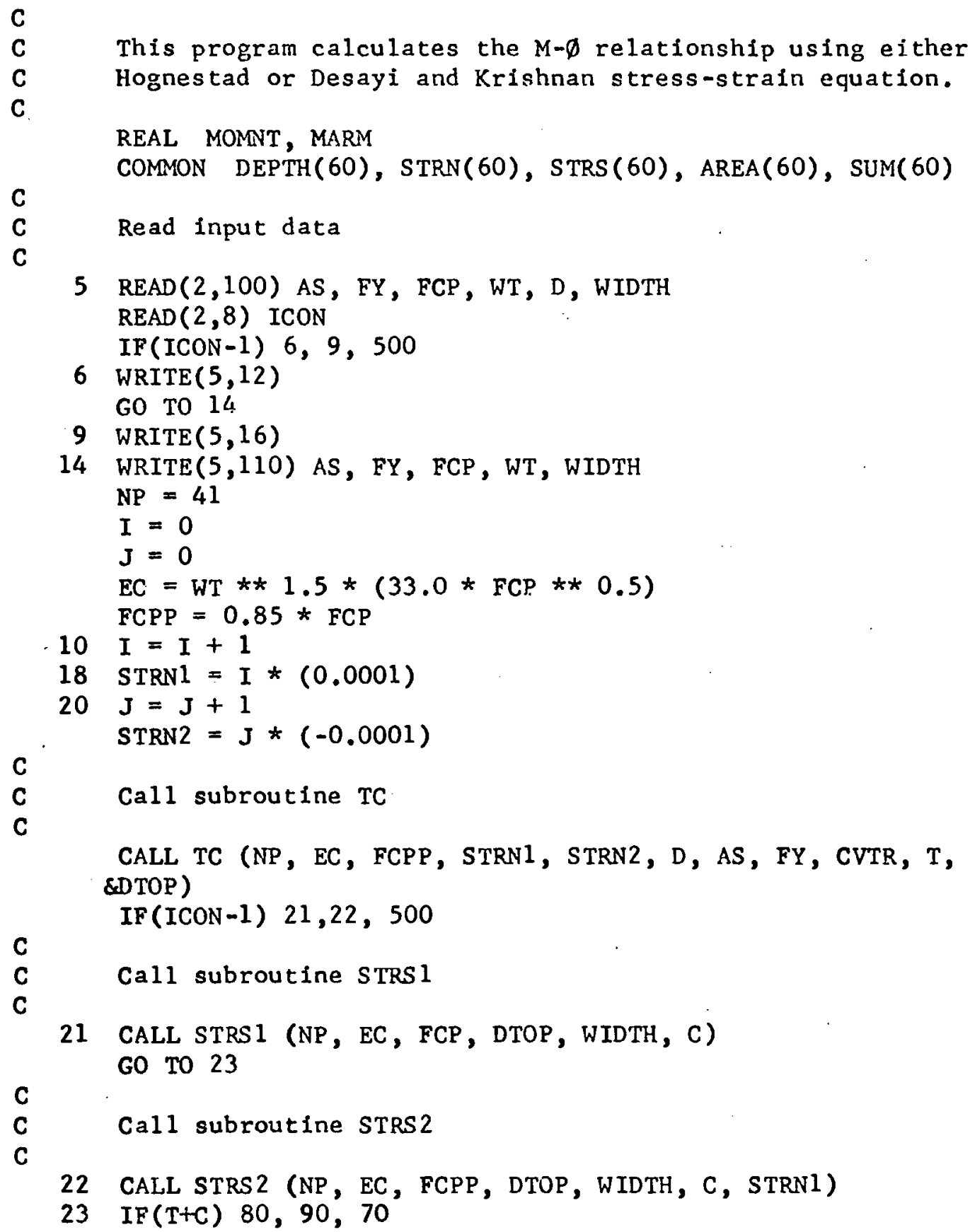




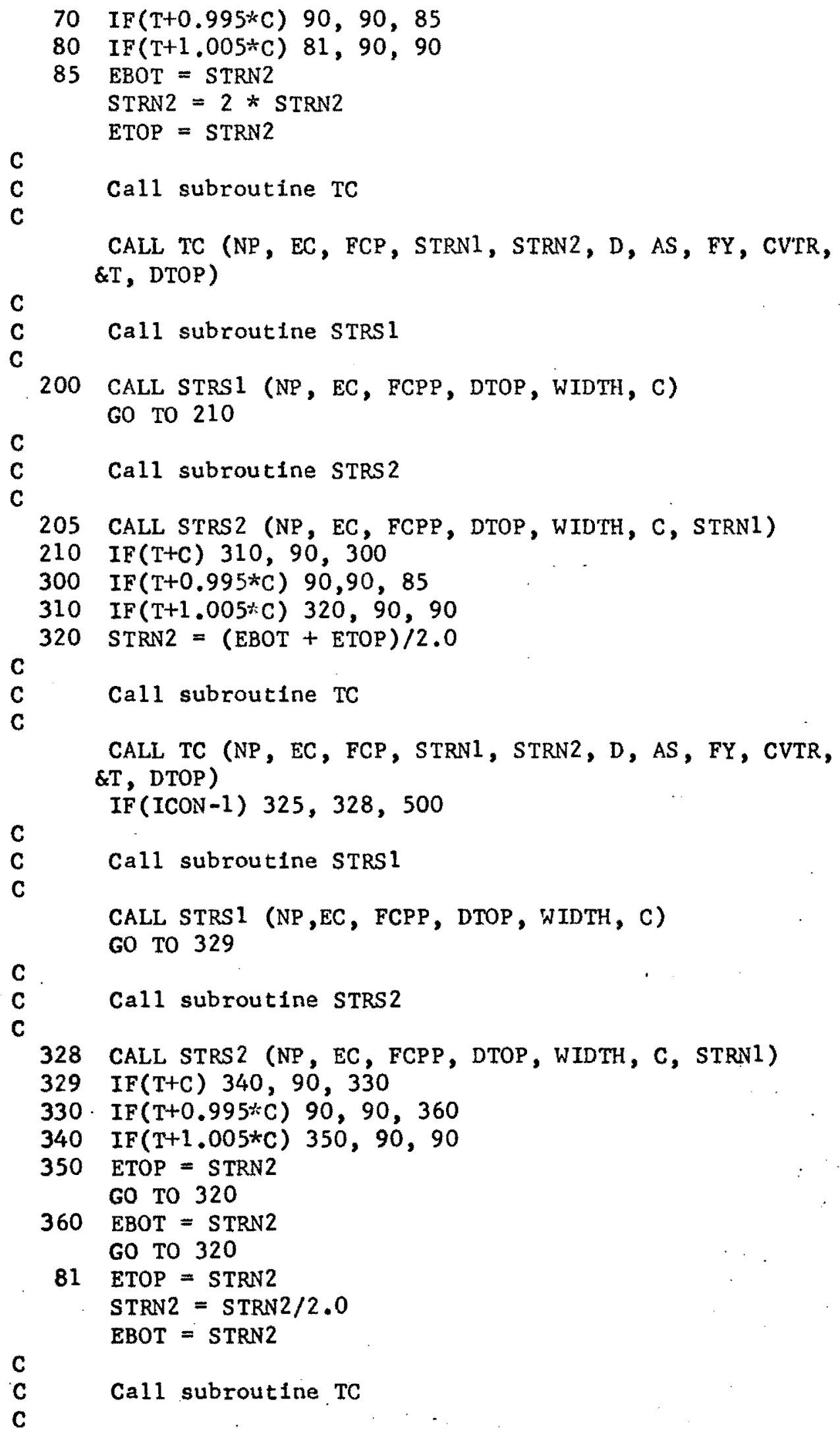


CALL TC (NP, EC, FCP, STRN1, STRN2, D, AS, FY, CVTR, \&T, DTOP)

$\mathrm{C}$ IF (ICON-1) $362,365,500$

C

C

362 CALL STRS 1 (NP, EC, FCPP, DTOP, WIDTH, C) GO TO 368

C

C

C

Cal1 subroutine STRS2

365 CALL STRS2 (NP, EC, FCPP, DTOP, NIDTH, C, STRN1)

$368 \operatorname{IF}(\mathrm{T}+\mathrm{C}) 375,90,370$

$370 \operatorname{IF}(\mathrm{T}+0.995 * \mathrm{C}) 90,90,320$

$375 \operatorname{IF}(\mathrm{T}+1.005 * \mathrm{C}) 81,90,90$

90 CONTINUE

DO $92 \mathrm{~K}=1, \mathrm{NP}$

$92 \operatorname{SUM}(K)=0.0$

DO $95 \mathrm{~K}=2, \mathrm{NP}$

$95 \operatorname{SUM}(K)=\operatorname{SUM}(K-1) * \operatorname{STRS}(K-1) * \operatorname{DPTH}(K-1)$

DO $97 \mathrm{~K}=1$, NP

$97 \operatorname{STRS}(K)=\operatorname{STRS}(K)+\operatorname{STRS}(K-1)$

CNTRD $=\operatorname{SUM}(N P) / S T R S(N P)$

MARM $=(D-(D T O P-C N T R D))$

MOMNT $=(-T+C) * 0.5 *$ MARM

WRITE $(5,130)$ STRN1, STRN2

WRITE $(5,140)$ STRS(i)

WRITE $(5,150)$ T, C, MARM, CVTR, MOMNT

IF (STRN 1 - 0.0038) 10,5,5

8 FORMAT (I1)

12 FORMAT $(/ /, 3 \mathrm{X}, " M-\emptyset$ CALC. USING KRISHNAN AND DESAYI \&EQUATION ")

16 FORMAT $(/ /, 3 X, " M-\emptyset$ CALC. USING HOGNESTAD EqUATION ")

100 FORMAT $(6 \mathrm{~F} 12.0)$

110 FORMAT $(3 \mathrm{X}, "$ AS $=$ ", F8.4, "IN. $\star \star 2$ ", $3 \mathrm{X}$, " FY = ", \&F8.0, "PSI ", 3X, "FCP = ", F8.0," PSI ", $1 /, 3 \mathrm{x}$, \& "WT $=$ ", F6.2, "PCF ", 3X, " D = ", F6.2, " IN.", $\& 3 \mathrm{X}$, " WIDTH $=$ ", F6.2, "IN. ", ///)

130 FORMAT $(3 \mathrm{X}, "$ CONCRETE STRAIN $=", F 9.7,5 \mathrm{X}$, " STEEL \& STRAIN $=", F 10.7$ )

140 FORMAT $(3 \mathrm{X}, "$ CONCRETE STRESS $=$ ", F12.4, //)

150 FORMAT $(5 \mathrm{X}, " \mathrm{~T}=$ ", F12.0, " $\mathrm{C}=$ ", F12.0, "MARM $=$ ", \& F12.6, $/ 1,5 \mathrm{X}, "$ CVTR $=", F 12.6, "$ MOMENT $=", F 12.2, /$ )

500 CALL EXIT

END 


\section{SUBROUTINE TC}

C

C

C

C

This subroutine calculates the curvature and the tension force.

SUBROUTINE TC (NP, EC, FCP, STRN1, STRN2, D, AS, FY,

\& CVTR, T, DTOP)

CONMON DPTH $(60), \operatorname{STRN}(60), \operatorname{STRS}(60), \operatorname{AREA}(60), \operatorname{SUM}(60)$

$E S=29400000.0$

27 CVTR $=($ STRN $1-S T R N 2) / D$

DTOP $=$ STRN $1 /$ CVTR

DO $40 \mathrm{~K}=1, \mathrm{NP}$

DPTH $(K)=$ DTOP $-($ DTOP $*(K-1)) / 40.0$

$40 \operatorname{STRN}(K)=(\operatorname{STRN} 1 * \operatorname{DPTH}(K)) / \mathrm{DTOP}$

$\mathrm{T}=\mathrm{STRN} 2 * \mathrm{ES} * \mathrm{AS}$

$\mathrm{T} 1=-\mathrm{AS} * \mathrm{FY}$

IF $(\mathrm{T} 1-\mathrm{T}) 43,43,42$

$42 \mathrm{~T}=\mathrm{T} 1$

43 RETURN

END

\section{SUBROUTINE STRS1}

C

C

C

C

This subroutine calculates the compression force using

Desayi and Krishnan stress-strain equation.

SUBROUTINE STRSI

COMMON DPTH $(60), \operatorname{STRN}(60), \operatorname{STRS}(60), \operatorname{AREA}(60)$

23 DO $25 \mathrm{~K}=1, \mathrm{NP}$

$25 \operatorname{AREA}(K)=0.0$

DO $10 \mathrm{~K}=1, \mathrm{NP}$

$A=E C * \operatorname{STRN}(K)$

$B=(A /(2.0 *$ FCPP $)) *(A / 2.0 * F C P P))$

$10 \operatorname{STRN}(K)=\operatorname{AREA}(K-1)+(\operatorname{STRS}(K-1)+\operatorname{STRS}(K)) *($ DTOP $*$

\& 0.0125)

$C=A R E A(N P) * W I D T H$.

RETURN

END 


\section{SUBROUTINE STRS2}

C

$\mathrm{C}$

C

This subroutine calculates the compression force using Hognestad stress-strain relationship.

C

SUBROUTINE STRS2 (NP, EC, FCPP, DTOP, WIDTH, C, STRN1)

COMMON DPTH(60), $\operatorname{STRN}(60), \operatorname{STRS}(60), \operatorname{AREA}(60)$

Do $25 \mathrm{~K}=1, \mathrm{NP}$

$25 \operatorname{AREA}(K)=0.0$

$\operatorname{IF}(S T R N 1-(2.0 *$ FCPP/EC $)) 30,30,50$

30 Do $40 \mathrm{~K}=1, \mathrm{NP}$

$A=E C * \operatorname{STRN}(K)$

$B=(A /(2.0 * F C P P)) *(A / 2.0 * F C P P))$

$40 \operatorname{STRS}(K)=(A-F C P P * B)$

GO TO 70

$50 \operatorname{STRS}(1)+\mathrm{FCPP}-0.15 * \mathrm{FCPP} *((\mathrm{STRNI}-(2.0 * \mathrm{FCPP}$

$\& / \mathrm{EC})) /(0.0038-(2.0 * \mathrm{FCPP} / \mathrm{EC})))$

Do $60 \mathrm{~K}=1, \mathrm{NP}$

$60 \operatorname{STRS}(K)=(\operatorname{STRS}(1) \star \operatorname{DPTH}(K)) / \mathrm{DTOP}$

70 DO $80 \mathrm{~K}=2$, NP

$80 \operatorname{AREA}(K)=\operatorname{AREA}(K-1)+(\operatorname{STRS}(K-1)+\operatorname{STRS}(K) *(\mathrm{DTOP} *$ \& 0.0125$)$

$\mathrm{C}=\operatorname{AREA}(\mathrm{NP}) *$ WIDTH

RETURN

END 